\title{
15. INITIAL TECTONIC DEFORMATION OF HEMIPELAGIC SEDIMENT AT THE LEADING EDGE OF THE JAPAN CONVERGENT MARGIN
}

\author{
Michael A. Arthur, U.S. Geological Survey, Denver, Colorado \\ Bobb Carson, Department of Geological Sciences and Center for Marine and Environmental Studies, \\ Lehigh University, Bethlehem, Pennsylvania \\ and \\ Roland von Huene, U.S. Geological Survey, Menlo Park, California
}

\begin{abstract}
Diatomaceous mudstones at depth under the deep sea terrace and the trench inner slope off Japan have been variably affected by tectonic stress. Veins, healed fractures, and microfaults occur at all sites except the shallow Site 435 on the upper trench inner slope and Site 436 on the Pacific Plate. Veins, fractures, and faults occur in cores from below 620 meters (lower to middle Miocene) in the landward sites ( 438 and 439 ) on the deep sea terrace, and are probably related to normal faulting seen in seismic records. The depth to "consolidated" sediment and to the first occurrence of veins and healed fractures shallows progressively toward the trench. The intensity of deformation also appears to increase seaward. However, no sediments younger than upper Pliocene are deformed. Open fractures may exist in situ at Sites 434 and 441 at levels between about 150 and 500 meters sub-bottom.

The Japan Transect sediments-in contrast to deposits in the zone of initial deformation at other convergent margins-though highly deformed, are not highly overconsolidated. However, sediment at depth in the trench inner slope sites is overconsolidated relative to that at the same depth in the landward reference site. None of the deformed Japan margin sediments recovered at Legs 56 and 57 sites originated by accretion of oceanic plate material-also in contrast to sediments at some of the margins previously studied. We suggest that tectonic stress related to convergence has been communicated to the slope sediments on the trench inner slope, either continuously or periodically, causing rapid tectonic dewatering and inducing fracturing and faulting. If episodic, the latest of these deformational periods may have occurred during the late Pliocene. The faults and fractures are either rehealed by continued overburden pressure (sediment loading) or may remain open at shallower levels. Fracturing and dewatering of semiconsolidated sediment beneath an unconsolidated but impermeable mud veneer may cause overpressured zones at depths of 200 to 500 meters. These overpressured zones possibly locally reduce shear strength and cause downslope mass movement of sediment, even on low-angle slopes on the trench inner slope.
\end{abstract}

\section{INTRODUCTION}

The IPOD active margins program has as a principal objective the study of subduction and such related processes as subduction accretion. The products of subduction accretion are unique to convergent margins (see Seely et al., 1974; Dickinson and Seely 1979, for review), but in modern margins that they are essentially inaccessible and their structure has proven difficult to resolve in seismic reflection records. Therefore, study that combines drilling with geophysical methods is appropriate.

The Japan fore-arc region (Figure 1) was selected for study because of its high rate of convergence with the oceanic plate $(8-10 \mathrm{~cm} / \mathrm{yr}$., Minster et al., 1974), because much of it appears to have only a thin Quaternary terrigenous sediment blanket, and because of its unique setting in which the Pacific Plate converges with an insular arc composed of continental crust associated with an opening back-arc basin. These conditions seemed favorable for study of the tectonic deformation associated with convergence because (1) over a thousand kilometers of oceanic crust are inferred to have been subducted since the early Miocene and (2) the sediment cover is sufficiently thick to record the associated deformation but not so thick as to mask it.

Much of the direct evidence for deformation along modern margins must be obtained by sampling, because 


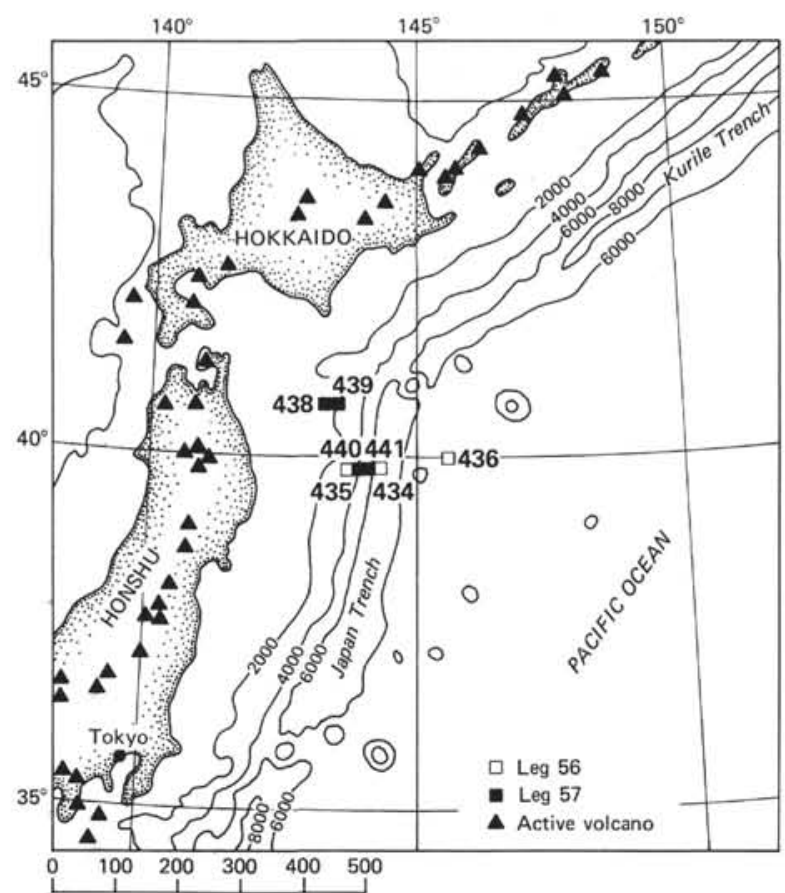

A

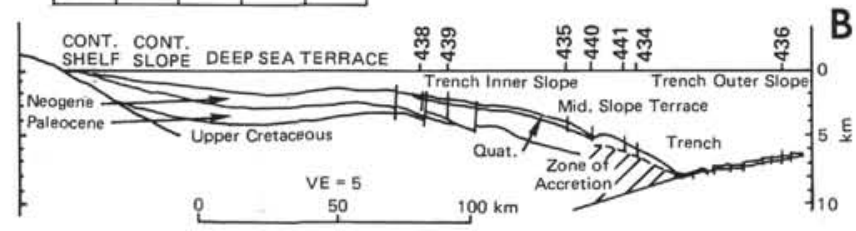

Figure 1. A. Index map to location of sites drilled on DSDP/IPOD Legs 56 and 57 off Northern Honshu and position of multichannel records JNOC 1 and 2 shown in Figure 2. B. Schematic cross section of Japan continental margin.

the seismic reflection technique is unable to resolve tight folds and closely spaced faults, especially in the great water depths associated with trenches and with high-angle, irregular trench inner slopes. The Japan Trench Transect was designed to include sampling at reference sites landward and seaward to the zone of accretion and at three sites within the seismically defined zone of accretion inferred from study of seismic records (Figure 2 ). However, on the trench inner slope, no sampled sediment could unequivocably be identified as derived from the oceanic plate, nor was there strong evidence from drilling for major or steady state accretion (see von Huene et al., summary, this volume). Recovered were highly fractured and microfaulted sediments of Neogene age having the same basic lithology as the unfractured landward reference sections. The slope sediments were affected by stress without having been deeply buried, extensively folded, or cut by major thrust faults.

Sediment consolidates in response to applied stress. If the stress is generated by burial, a simple stress field results, with the principal axis oriented vertically. Consolidation proceeds as long as the lithostatic load can act to expel interstitial fluids. In the fore-arc region associated with a subduction zone, the stress field is presumably a combination of both lithostatic and tectonic stresses, and although it can be modeled (Hafner, 1951; Hubbert, 1951), its true configuration has not been verified by observation. Consolidation studies in subduction zones may delineate tectonically stressed areas as distinct from normal lithologic compaction. The difficulty with such studies is that in situ lithostatic loading may result in complex dewatering patterns, depending on lithology, texture, and degree of cementation, and there is no way of predicting what the effects will be at a particular site. The best that can be done at the present time is to describe deviations from the present concepts of normal consolidation (e.g., Hamilton, 1976); if there are patterns common to several subduction complexes, generalizations concerning the tectonic stress field, and sediment response to it, can be drawn. This chapter, then, describes postdepositional modification of sediment on the Japan Trench inner slope, and we hope it will provide a reference section for comparison with those of other convergent margins.

\section{GEOLOGIC HISTORY AND STRUCTURE}

The present episode of plate convergence on northern Honshu probably began in the latest Oligocene (for review, see Honza et al., 1977) with the initial development of the present magmatic arc. During the present episode of plate convergence, the fore-arc region has subsided throughout the Miocene and Pliocene. In the area of the drill sites, an ancient landmass composed of Cretaceous and perhaps some Paleogene rocks began to subside in the late Oligocene. The last remnant of the subaerially exposed landmass, Oyashio, subsided below sea level in the late Miocene. A seaward transgressive sequence of Paleogene and Neogene sediment was deposited unconformably on the subsiding landmass, which was subaerially eroded prior to subsidence. Superimposed on regional subsidence was local tectonism that produced minor high and low areas (Honza et al., 1977). During the late Pliocene, however, subsidence ceased and the area was uplifted, the midslope terrace formed, and an area of sediment-trapping on the lower trench inner slope destroyed, possibly by slumping of large masses of slope sediment (see Arthur et al., this volume).

The landward reference sites (438 and 439) are on the flank of a broad local structural high dominated by small normal faults (see Nasu et al., this volume). The seaward reference site (436) is also in an area of normal faulting on the trench outer slope. Therefore these sites should reflect structure in areas of predominantly noncompressional stress, but, as the normal faults show, they do not represent an entirely tectonically unstrained environment in which only lithostatic loading prevails.

It is not clear from the seismic records exactly where on the trench inner slope compressive strain might become dominant. The normal-faulted deep-sea terrace reflective sequence can be traced from the landward reference site seaward across a broad arch at the edge of the deep sea terrace and down the trench inner slope to the midslope terrace. With increasing depth, the reflective sequence is increasingly obscured by diffractions (Fig- 

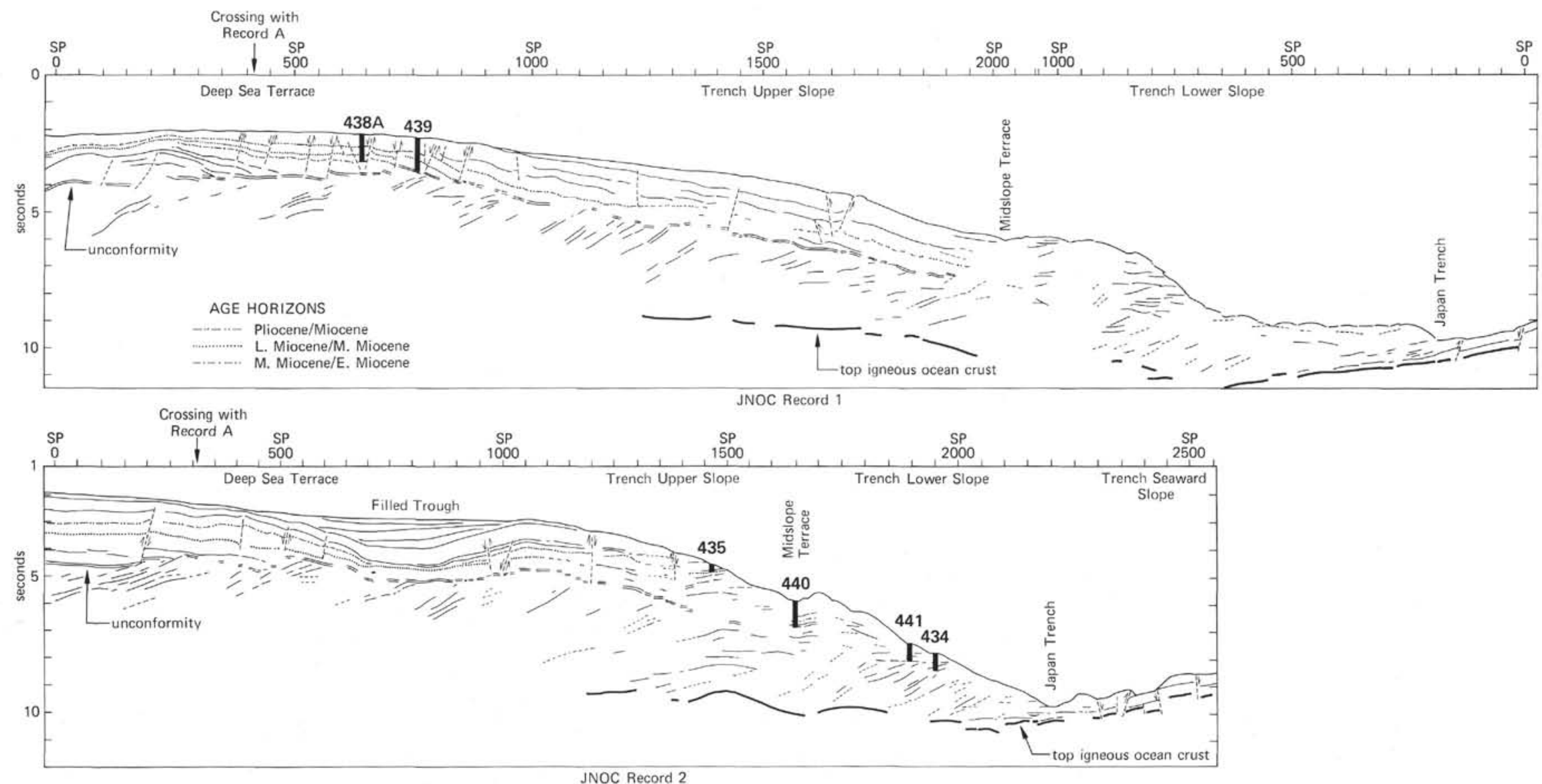

Figure 2. Sketch of multichannel seismic records JNOC 1 and 2 (see Nasu et al., this volume) across the Japan Trench convergent margin, showing major structural features, seismic units, and location of Legs 56 and 57 drillsites. 
ure 2). Some diffractions mark slump or fault zones, and because both slumps and faults are seen at the seafloor, either can be inferred at depth. The terrace sequence was sampled by drilling as far seaward as the midslope terrace (Site 440), a sharp inflection in the trench inner slope. Seaward of the midslope terrace, the structure in seismic records changes. Faint reflections dip landward above the top of reflections from the igneous crust, resembling models of accretionary prisms (e.g., Seely et al., 1974), and thus accretion is inferred (Figure 1B and Figure 2). The inferred accretionary prism is covered by slope deposits ranging in age from Pleistocene to upper Miocene (site chapters for Sites 441 and 434 , this volume, Pt. 1). The top of the accretionary prism may have been sampled in the lower part of Site 434. The midslope terrace appears to mark the approximate junction between a continental section and a subduction accretion complex. The midslope terrace may in fact be the fundamental boundary between continental crust and the seaward accreted material, as Marauchi and Ludwig (this volume) conclude from their study of seismic refraction data. The age of this boundary is projected as early Miocene (see Site chapter for Site 440). Structure on the upper part of the trench inner slope immediately landward of the midslope terrace can be interpreted as either extensional or compressional (see Nasu et al., this volume). Reflectors crop out on the trench inner slope (Figure 2), which suggests that slumping of some of the slope sequence has occurred.

\section{PHYSICAL PROPERTIES AND LITHOLOGY OF SEDIMENTS}

The Neogene sediment sampled at all IPOD drill sites on the Japan Trench Transect is a fairly uniform hemipelagic mudstone deposited at rates of from 30 to 150 $\mathrm{m} / \mathrm{m}$.y. from the Miocene through the Pliocene (Figure 3). Pleistocene sediment is coarse grained but does not concern us here, since it is not involved in fracturing. Lithologic uniformity is affected most by diatom content, which varies from 10 to 30 per cent within and among sites, but may be locally as high as 60 per cent (see Arthur et al., this volume). Diatom content may also affect the compressibility of sediments, especially at relatively low overburden pressures (e.g., Hamilton, 1976). Diatom content at the sites on the lower part of the trench inner slope is somewhat lower than at the landward reference sites. We might expect the sediment at the landward reference site to compact less readily at a given depth than that on the trench inner slope. However, the response of this sediment to stress is probably reasonably similar at all sites, and the comparison of fracturing between reference and slope sites should not be greatly complicated by variation in original physical properties.

The general uniformity of physical properties below the Pleistocene is reflected in shipboard determinations of bulk density, porosity, sonic velocity, and a suite of downhole geophysical logs (Figure 4). These measurements are reported in Carson and Bruns (this volume). Sonic velocity is particularly uniform from site to site in the Pliocene and upper Miocene sediment sequences, which accounts for the difficulty in differentiating these intervals in seismic reflection records.

\section{Measurement of Physical Properties}

The bulk density and sonic velocity curves presented in Figure 4 are visual estimates of the average distribution of density and velocity, derived from either shipboard determinations or downhole geophysical logs (Carson and Bruns, this volume). Processed logs (Saki et al., this volume) of formation density (Sites 438, 439, 440 , and 441) and sonic velocity (Sites 438, 439, and 440 ) were smoothed visually to remove short wavelength (5-m vertical extent) events. Shipboard determinations of bulk density (gravimetric and GRAPE) and sonic velocity are the only data available for Sites 434,435 , and 436. Extreme values, which represent local variations in lithology (e.g., carbonate cementation, ash layers, etc.), were not incorporated into the generalized profiles in Figure 4.

Void ratios $(e)$ and associated lithostatic pressures $(\bar{p})$ were calculated for Sites 438, 439, 440, 441, and 434 . Bulk density $(\gamma)$ values were taken from the processed formation density logs (shipboard determinations, Site $434)$ at 10 -meter intervals and converted to void ratios according to the equation given by Richards et al. (1974):

$$
e=44.749-53.998 \gamma+20.586(\gamma)^{2}-2.2317(\gamma)^{3} .
$$

The overburden pressure $\left(\bar{p}\right.$, in $\left.\mathrm{kg} / \mathrm{cm}^{2}\right)$ is calculated by $\bar{p}=\left(\gamma-\gamma_{\mathrm{sw}}\right) z$, where $\gamma_{\mathrm{sw}}=$ bulk density of seawater (taken to be $0.1025 \mathrm{~kg} / \mathrm{cm}^{3}$ ) and $z=$ depth increment $(1000 \mathrm{~cm})$. The distribution of $\bar{p}$ with depth is determined by incrementally summing the computed values of $\bar{p}$ downhole.

\section{Physical Properties Data}

\section{Fore-arc (438 and 439) and Deep Ocean (436) Sites}

Bulk (formation) density and sonic velocity generally increase with depth at Sites 438, 439, and 436 (Figure 4). Perturbations in this pattern reflect, in large part, lithologic or textural variations.

At Sites 438 and 439 , density decreases from $\sim 1.68$ $\mathrm{Mg} / \mathrm{m}^{3}$ at the surface to $\sim 1.47 \mathrm{Mg} / \mathrm{m}^{3}$ (in situ $\log$ ) or $\sim 1.35 \mathrm{Mg} / \mathrm{m}^{3}$ (shipboard determinations) at $130 \mathrm{me}-$ ters, paralleling a decline in sand content. Between 130 and 530 meters, the bulk density of the diatomaceous claystone increases slightly but regularly from 1.47 to $1.53 \mathrm{Mg} / \mathrm{m}^{3}$ (in situ logs) or 1.35 to $1.50 \mathrm{Mg} / \mathrm{m}^{3}$ (shipboard determinations). Broad excursions mark the density profile below 550 meters. Density highs may reflect decreased diatom content, increased sand-gravel content, and/or carbonate cementation; the density low $\left(\sim 1.55 \mathrm{Mg} / \mathrm{m}^{3}\right.$, in situ $\log ; 1.40 \mathrm{Mg} / \mathrm{m}^{3}$ shipboard determinations) at 790 to 810 meters is apparently the result of pervasive, small-scale faulting, as no lithologic change is evident.

Bulk density at Site 436 (Figure 4) increases from $\sim 1.43 \mathrm{Mg} / \mathrm{m}^{3}$ at the surface to $1.50 \mathrm{Mg} / \mathrm{m}^{3}$ (shipboard determinations) at 360 meters in mudstones, which are diatomaceous and/or vitric. Variations in the abun- 


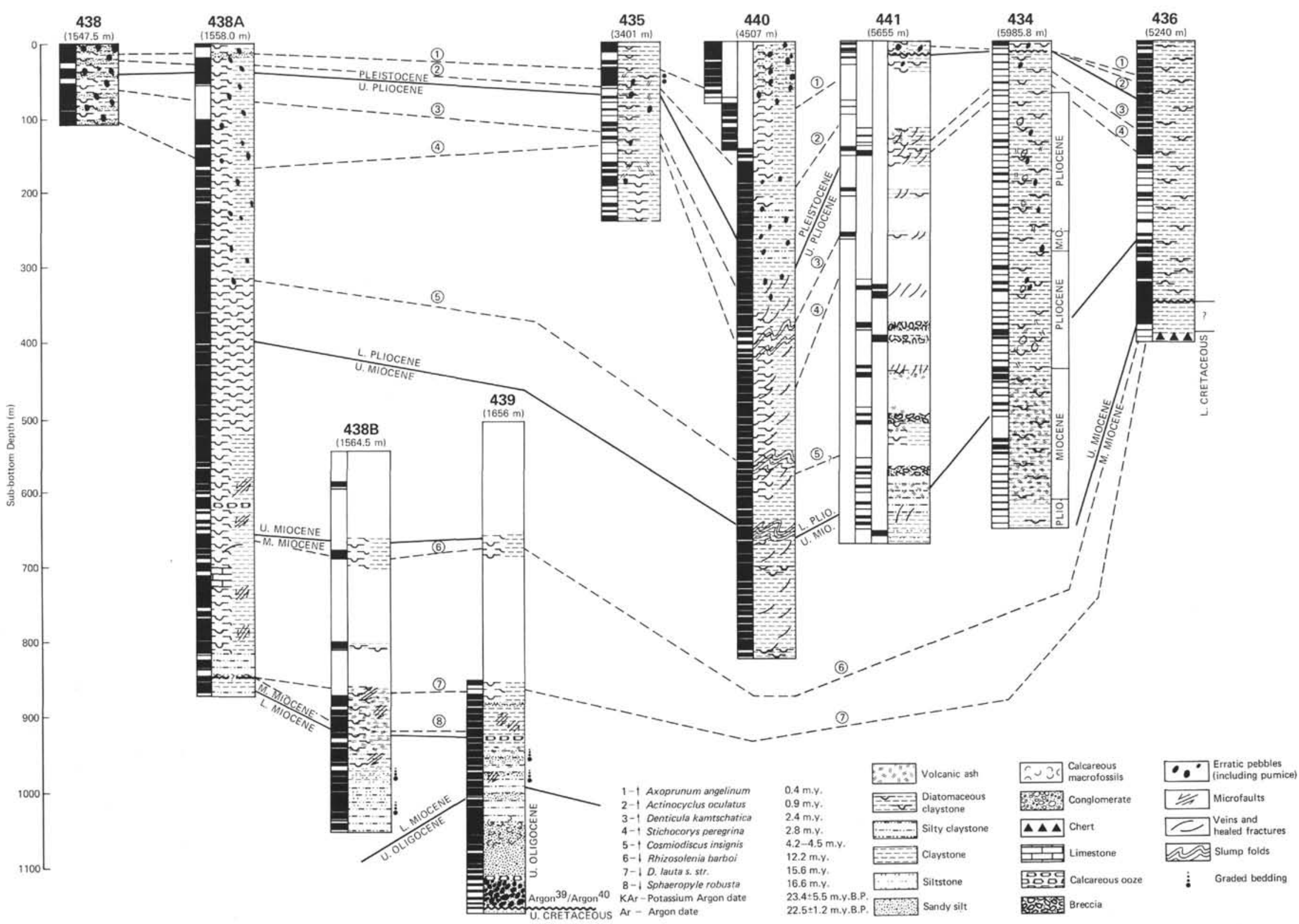

Figure 3. Lithology and age of sediments recovered in drill sites from DSDP/IPOD Legs 56 and 57. 


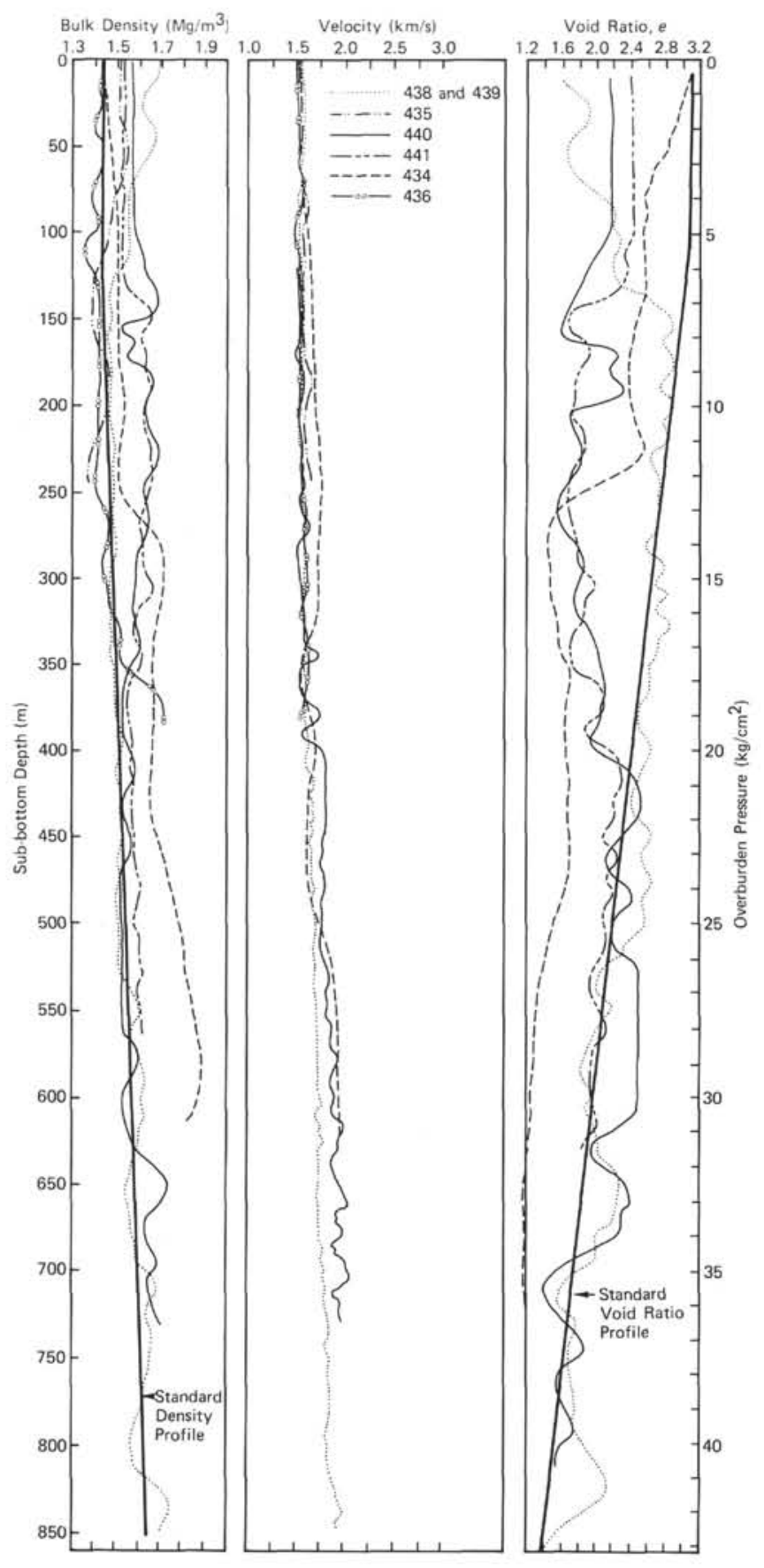

Figure 4. Bulk density and sonic velocity profiles plotted as a function of depth. Density profiles for Sites 438, 439, and 440, and 441 are based on in situ logs; Sites 434, 435, 436 are based on shipboard (gravimetric and GRAPE) determinations. Origin of the standard density profile is described in the text. Velocity profiles for Sites 438, 439, and 440 are based on in situ logs; Sites 434, 435, and 436 profiles reflect shipboard determinations. Void ratio-pressure profiles are derived from the bulk density plots. The pressure and depth scales are not comparable. dance of these lithologic components apparently give rise to the fluctuations $\left(0.05-0.07 \mathrm{Mg} / \mathrm{m}^{3}\right)$ in density above 360 meters. Densities below 360 meters increase markedly (to $1.70-1.75 \mathrm{Mg} / \mathrm{m}^{3}$ ) in pelagic clay and chert. The latter lithologies are not encountered at any other site on the transect and hence are of little comparative value.

Although the density profiles at Sites 438,439 , and 436 are not coincident (Figure 4), the disparities between them appear to be the result of minor lithologic or textural differences and/or instrumental effects rather than a fundamentally different consolidation history.

The lack of agreement between the two bulk density profiles from 100 to 250 meters can be attributed to the use of incorrect grain densities $\left(2.65 \mathrm{Mg} / \mathrm{m}^{3}\right.$ instead of the actual $2.50 \mathrm{Mg} / \mathrm{m}^{3}$ ) in processing the in situ logs at Sites 438 and 439 . Shipboard determinations over this interval are coincident at the two sites (Carson and Bruns, this volume). Below 380 meters, the ash and diatom contents at Site 436 decline markedly, and as a result densities are 0.05 to $0.30 \mathrm{Mg} / \mathrm{m}^{3}$ higher than comparable determinations at Sites 438 and 439 , in more diatomaceous sediments.

A reference (or standard) bulk density profile for diatomaceous mudstones is depicted in Figure 4, and is based on results from Sites 438,439 , and 436 but "corrected" for lithologic and textural variations. Densities in the upper 130 meters are nearly constant at 1.43 $\mathrm{Mg} / \mathrm{m}^{3}$ (value observed at Site 436 ; the near-surface density at 438 and 439 is anomalous because of the high sand and gravel content). Below 130 meters, densities increase (as at Sites 438 and 439, Figure 4) linearly from $1.43 \mathrm{Mg} / \mathrm{m}^{3}$ to $1.63 \mathrm{Mg} / \mathrm{m}^{3}$ at 800 meters.

Sonic velocities at Sites 438, 439, and 436 are virtually identical, increasing from $-1.50 \mathrm{~km} / \mathrm{s}$ at the surface to $1.60 \mathrm{~km} / \mathrm{s}$ at 350 meters (Figure 4). The velocity at 438 and 439 continues to increase linearly at greater depths, reaching $1.85 \mathrm{~km} / \mathrm{s}$ at 800 meters. Variations in lithology (e.g., 350-380 $\mathrm{m}$ at Site 436) or texture (e.g., $0-130 \mathrm{~m}$ at Sites 438 and 439 ), which are reflected in the bulk density profile, have a relatively minor effect (perturbations of $0.02-0.05 \mathrm{~km} / \mathrm{s}$ ) on sonic velocity.

\section{Trench Inner Slope Sites $(435,440,441$, and 434)}

Sites 440,441 , and 434 , situated on the middle to lower part of the trench slope, exhibit physical properties which are distinctly different from those described for Sites 438, 439, and 436. Site 435, from the upper trench slope, may represent a transition zone between the shelf and slope samples, but because penetration was not sufficiently deep, a valid comparison cannot be made.

Bulk density at Sites 440 and 441 (Figure 4) increases irregularly with depth from near-surface densities of 1.52 to $1.56 \mathrm{Mg} / \mathrm{m}^{3}$. At both sites a subsurface density maximum is observed: $1.69 \mathrm{Mg} / \mathrm{m}^{3}$ at 225 meters, in situ $\log$, Site 440 , or, $\sim 1.80 \mathrm{Mg} / \mathrm{m}^{3}$ at 410 meters, shipboard determinations, Site $440 ; \sim 1.67 \mathrm{Mg} / \mathrm{m}^{3}$ at 235 meters, in situ log, Site 441 . Below this density maximum, values decline to a uniform density minimum which persists over a considerable vertical interval: 1.53 
to $1.55 \mathrm{Mg} / \mathrm{m}^{3}, 410$ to 470 meters, Site $440 ; 1.55$ to 1.57 $\mathrm{Mg} / \mathrm{m}^{3}, 380$ to 460 meters, Site 441 . Downhole logs indicate that the low density zones are also zones of minimal density variability $\left(0.07 \mathrm{Mg} / \mathrm{m}^{3}\right.$; Figures 5 and 7 in Carson and Bruns, this volume). Below the density minima, values increase to the base of the holes $\left(\sim 1.62-1.65 \mathrm{Mg} / \mathrm{m}^{3}\right)$.

Site 434 exhibits a much different density profile (Figure 4). Near-surface densities $\left(1.43 \mathrm{Mg} / \mathrm{m}^{3}\right.$ surface, to $1.53 \mathrm{Mg} / \mathrm{m}^{3}, 200 \mathrm{~m}$ ) are lower than those observed at Sites 440 and 441 . At about 220 meters, however, the density increases markedly (to $\sim 1.7 \mathrm{Mg} / \mathrm{m}^{3}$ ) and remains considerably higher than densities observed at any other site, attaining values of $1.88 \mathrm{Mg} / \mathrm{m}^{3}$ at 600 meters. A zone of minimum density $\left(1.65 \mathrm{Mg} / \mathrm{m}^{3}\right)$ is apparent between 350 and 440 meters.

Each of these sites exhibits bulk densities which are significantly greater (by as much as $0.17-0.32 \mathrm{Mg} / \mathrm{m}^{3}$ ) than corresponding densities at Sites 438, 439, or 436 . (Figure 4). With the exception of 434, anomalously high densities are restricted to the upper 400 meters. Beneath the upper, high-density zone ( $230 \mathrm{~m}$, Sites 440 and 441 ; 270-310 m, Site 434) the density gradient reverses, suggesting incomplete consolidation and perhaps the presence of abnormally high pore pressures. The density minima defined by this pattern occur at progressively higher levels (465-565 m, Site 440; 360-410 m, Site 441; $350-430 \mathrm{~m}$, Site 434 ) and exhibit progressively greater (absolute) bulk densities $\left(1.52 \mathrm{Mg} / \mathrm{m}^{3}\right.$, Site $440 ; 1.55$ $\mathrm{Mg} / \mathrm{m}^{3}$, Site $441 ; 1.65 \mathrm{Mg} / \mathrm{m}^{3}$, Site 434 ) from west to east, toward the trench axis.

The density reversal which occurs in all three holes is observed both in the downhole logs (Sites 440 and 441) and in shipboard determinations (Sites 440 and 434). However, at Site 440, the only hole for which both sets of density data are available, the density profiles differ. The disparity in the results may provide information on the mechanism which causes the decline in bulk density.

Both sets of density data at Site 440 are coincident above 250 meters (figure 5 in Carson and Bruns, this volume). Between 250 and 410 meters, however, in situ densities decline (from 1.70 to $1.55 \mathrm{Mg} / \mathrm{m}^{3}$ ), whereas the gravimetric density data increase regularly to 1.80 $\mathrm{Mg} / \mathrm{m}^{3}$. At 410 meters, the shipboard determinations decline abruptly to $1.55 \mathrm{Mg} / \mathrm{m}^{3}$ and are again coincident with the in situ values.

The disparity between shipboard and in situ results cannot be attributed to the use of incorrect grain densities $\left(2.65 \mathrm{Mg} / \mathrm{m}^{3}\right.$ rather than actual $\left.2.50 \mathrm{Mg} / \mathrm{m}^{3}\right)$ in processing the geophysical logs. Although the higher value was used, the effect is to generate unrealistically high in situ densities rather than values which are too low (Carson and Bruns, this volume).

The decline in in situ densities between 250 and 410 meters might alternatively be attributed to hole washouts. However, the caliper log (run with the sonic tool, after the density determination) indicates that with minor exceptions the hole diameter was uniform.
An alternate explanation for the dichotomy between in situ and shipboard densities relates to the veining and/or fracturing observed at Site 440. As described in greater detail in the following, veins appear at 250 meters and fractures with small of fsets are observed at and below 280 meters. If the gradual decline in in situ densities, which begins at about 250 meters, is a function of vein and/or fracture voids, the implication is that either individual fracture volume or fracture frequency increases downhole. The latter possibility seems more reasonable, because widely spaced $(>1-\mathrm{cm})$ fractures would affect the in situ log, whereas only closely spaced $(\leq 1-\mathrm{cm})$ fractures would be reflected in the shipboard data. Whether or not the fracture density becomes sufficiently high only at this depth (and thus accounts for the rapid decline in shipboard bulk densities), however, cannot be uniquely established from examination of the cores because core recovery was intermittent and much of the recovered material was of poor (fragmented) quality. If the density decline is related to the occurrence of veins and/or fractures, however, the disparity in the data may reflect the scale and/or intensity of brittle failure.

Sonic velocities over some sections of Sites 440 and 434 are anomalously high in comparison with velocities at Sites 438, 439, and 436 (Figure 4). At Site 440, sonic velocity increases rapidly at 400 meters (approximately the same depth at which shipboard density determinations decrease markedly) from 1.58 to $1.81 \mathrm{~km} / \mathrm{s}$. Below 400 meters, the velocity at Site 440 increased to $2.0 \mathrm{~km} / \mathrm{s}$ at 730 meters and is consistently 0.1 to $0.3 \mathrm{~km} / \mathrm{s}$ higher than velocities at Sites 438 and 439 at comparable depths. The zone of minimum density defined by the in situ $\log (465-560 \mathrm{~m}$, Site 440$)$, is reflected only by a very minor decline $(0.04 \mathrm{~km} / \mathrm{s})$ in the velocity profile.

At Site 434 , anomalously high velocities $(1.75 \mathrm{~km} / \mathrm{s})$, which bear no relationship to the density distribution, occur between 100 and 330 meters. A second high velocity $(1.94 \mathrm{~km} / \mathrm{s})$ section lies below 500 meters, in a highdensity zone. Between these two sequences $(330-500 \mathrm{~m})$, the sonic velocity is notably low $(1.55-1.70 \mathrm{~km} / \mathrm{s})$ and similar to equivalent velocities at Sites 438 and 439 . This low-velocity zone corresponds generally to a section of lower densities.

At both Sites 440 and 434 there is little obvious correlation between bulk density and sonic velocity at depths less than 450 (Site 434) to 570 meters (Site 440 ). At greater depths, at least a rudimentary similarity is apparent between the two sets of data. The zones in which velocity and bulk density appear to vary independently lie within the veined or fractured portions of each hole: anomalously high velocity at Site 434 begins at 80 meters (Figure 4), above the depth at which veining first occurs; the rapid increase in velocity at 400 meters at Site 440 occurs where veining and fracturing both occur and where shipboard densities decline markedly. It should be noted, however, that near the base of each hole, where the velocity and density show similar profiles, veining and fracturing are also common. Thus it is most 
likely that the low-density zones represent intervals with open, fluid-filled fractures in situ as well as healed fractures seen in the cores. Rehealed fractures would not be expected to lower bulk density or sonic velocity significantly. This aspect is explored later in this chapter.

\section{Lithification and Deformation Structures}

All cores from Legs 56 and 57 were visually examined at the DSDP core repository in La Jolla, California. We noted degree of lithification (e.g., as per Gealy et al., 1971), types of deformational features present, average orientations of these features relative to the split core face, and made a subjective estimate of the intensity of deformation (see Figure 5). Photographs of typical structures were taken at a number of scales for later comparison (see Plates 1-12). Thin sections were cut normal to bedding and/or representative structures in some cores for study of possible grain fabrics and microdeformation associated with veins, fractures, and faults. Standard $\mathrm{x}$-ray diffraction techniques and SEM and KEVEX (semiquantitative chemical analysis) were used to analyze some of the material filling veins and fractures and to compare it with adjacent sediment matrix. Later in this chapter we describe the deformation features in detail, by site.

\section{Definition of Terms}

Because the terms used in this chapter have many nuances of meaning, we provide the following definitions.

Veins: dark linear, curved, or anastomosing features (planar in geometry) crossing the face of the cut core at an oblique angle (usually near vertical) to bedding and showing no offset of other structures transected by the veins. The apparent width of veins depends on their orientation to the cut face, but the true thickness is generally less than $1 \mathrm{~mm}$. Vein fillings are usually darker (gray to black) than the surrounding rock matrix (usually olive-green gray) and finer grained. In calcareous intervals veins may be filled with sparry calcite. The use of "vein" in this paper implies a recognizable secondary structure in the sediment or rock which is a coherent part of that rock.

Fractures may be "open" or "closed" (rehealed) upon recovery of the core. In this chapter by "fractures" we mean those which are closed and can be demonstrated to be a primary structural feature of the rock, not those induced by the drilling or core-handling operations. They are planar on a large scale but often irregular on a small scale; occur at all angles oblique to bedding; are rehealed; and generally offset other features 1 $\mathrm{mm}$ or less. Fracture widths are typically less than 1 to 2 $\mathrm{mm}$; fine-grained dark fillings cement opposite planes.

Open or uncemented fractures may or may not have been open in situ. We distinguish these from definite in situ fractures by the word "open" in the text. However, in the absence of fracture fillings and core coherency, other evidence may be used to determine whether fractures existed open at depth prior to coring or were related to the drilling (see Appendix).

Faults: In the cores studied, faults are similar in appearance to fractures but are generally more planar and may exhibit offset greater than $1 \mathrm{~mm}$. We call them "microfaults" when they have up to 5 -cm relative of fset in both normal and reverse senses. Offsets greater than $5 \mathrm{~cm}$ are generally difficult to recognize because of the limitations imposed by core width and recovery.

Breccia: "Breccia" or "brecciated" is used loosely to describe core which has been so extensively fractured or microfaulted that the sediment appears chaotic. In such material pieces of the original sedimentary material are generally angular and less than 1 to $2 \mathrm{~cm}$ in diameter. Some breccias in the cores were obviously formed in situ, either by pervasive fracturing (the fractures having several orientations) or by redeposition from downslope mass flows. These breccia types can be observed only where they are recemented or rehealed. Another type of breccia is that recovered at Sites 434 and 441 , which consists only of a mass of chips of sedimentary material. In a few examples these chips fit together into coherent core pieces but were uncemented. The recovery of chips instead of coherent core may be due to the effect of drilling and release of pressure on an extensive open network of fractures in compacted mudstone, or it may result from parting along preferred orientations of platy textural components. The chips, generally less than $1 \mathrm{~cm}$ in diameter, resemble scaly argillite in texture. Grooved or steeped, somewhat smooth surfaces commonly occur on the chips (see Plate 12; also Moore, this volume).

\section{Sites 438 and 439-Landward Reference Sites}

The diatomaceous mudstone and clayey diatom ooze at Sites 438 and 439 becomes "lithified" (that is, too hard to cut with a cheese-slicer) at about 420 meters subbottom (Core 438A-39), but the trend toward lithification with depth is gradual. Soft layers are encountered down to about 520 meters. Sediment is unconsolidated and exhibits flow-in structures to about 120 meters subbottom. More competent ash and sand layers are less deformed than the semiplastic mud. Below 120 meters the sediment becomes stiff enough to cut with the bit; however, 1- to 2- cm sections of the core spin relative to one another, forming the typical "biscuit" structure (Plate 4, Figure 1). "Biscuiting" is well developed to about $850 \mathrm{me}-$ ters depth, where the sediment is indurated enough to allow recovery of long core segments. Lithification is apparently due to vertical compaction, with possible minor authigenic silica cementation (see Moore and Gieskes, Iijima et al., Arthur et al., this volume). Some zones cemented by low magnesian calcite and some massive limestone layers, commonly associated with volcanic ash layers, occur below about 360 meters. Bedding is horizontal or near horizontal from the sediment-water interface to about 850 meters, below which it dips between horizontal and about $30^{\circ}$ in a faulted zone.

Structures indicative of stress or strain release occur only below 600 meters depth (Core 438A-59). The first features of note are incipient veins which contrast with the olive green sediment. The sequential development of these veins is shown in Plate 1 . The veins have dark gray to black traces which are oriented near vertical. The 
traces are generally less than $0.5 \mathrm{~mm}$ thick and are discontinuous. Some vein sets are anastomosing and very irregular. The maximum length of any vein set noted in cores is about $10 \mathrm{~cm}$. Veins do not pass through coarsegrained layers but often feed into them. The material filling veins is finely comminuted clay minerals associated with minor amounts of sulfides. There is no difference in mineralogy between vein fillings and sediment matrix. Sigmoidal veins (Plates 2 and 3 ) are associated with the intersection of two or more healed fracture sets or microfaults below 620 meters.

The veins are interpreted as dewatering structures commonly associated with locally stressed intervals near large faults. Microfaults, fractures, and veins at Sites 438 and 439 occur at depths where faults have been identified in seismic reflection records, so that it is likely that the small-scale structural deformation is due to the stress associated with faulting. Veins and microfaults are restricted primarily to the interval between 620 meters in Hole 438A and 960 meters in Hole 439, mainly in sediment of early to middle Miocene in age. Healed fractures and microfaults are rare below 950 meters. This could in part be due to the predominantly coarse grained texture of sediment below this depth, but even interbedded mudstones are rarely fractured or veined.

Healed fractures and microfaults resemble veins. They have sinuous dark traces, generally less than $1 \mathrm{~mm}$ thick. It is often difficult to measure the true orientation of the fractures. Cores and core pieces may rotate relative to one another, which makes measurement spurious at best. Most healed fractures and microfaults are inclined between $45^{\circ}$ and vertical. Although some appear to be horizontal (Plate 2, Figures 1 and 2), inspection of the core piece shows that the core face nearly parallels the strike of the fracture surface and that the fracture plane dips at least $45^{\circ}$ to $50^{\circ}$. Microfaults exhibit relative offsets of usually less than $1 \mathrm{~cm}$. Most are normal faults, although small reverse faults also occur. The boundaries of most of the microfaults are sharp (e.g., Plate 3), suggesting deformation of the sediment after it was at least semilithified. However, the pattern of veins associated with the fractures suggests that the sediment still had significant water content at the time of deformation. Many sets of veins interconnect major fractures, and some terminate at coarser-grained layers. These veins were probably dewatering conduits for the stressed sediment and fed fluids to more permeable layers and major fractures, which were the primary avenues of water release from the stressed zone. There is some evidence for migration of gaseous hydrocarbons through parts of the fracture system (see Whelan and Hunt, this volume).

The material filling veins and fractures at Sites 438 and 439 is dark and consists of very fine-grained clay minerals, some quartz, and associated minor amounts of pyrite. There is a preferred orientation of elongate and platy grains within or along the margins of most fractures (Plates 12 and 13). This preferred orientation probably resulted from movement and shearing along the fracture plane and/or movement of fluids along the veins and fractures. Much of the very fine grained $(<2 \mu \mathrm{m})$ material may have been carried into the veins and fractures by fluids; some probably resulted from grain breakage along the fractures.

Healed fractures, microfaults, and veins occur sporadically through the interval from about 620 meters to 950 meters, mainly affecting sediment of late early Miocene and middle Miocene age. Zones of intense shearing occur (Plate 3), but these are separated by long, undeformed intervals. Open fractures are common but generally unsystematic. They are rarely related to trends of healed fractures in the same core. These open fractures were likely induced by core-handling (see Appendix). The zones of faulting and fracturing of the sediment at Sites 438 and 439 are probably related to local larger scale normal faulting, which can be seen in seismic records.

\section{Site 436-Seaward Reference Site}

About 360 meters of sediment of middle Miocene through Pleistocene age was recovered at Site 436 seaward to the trench. The sediment- vitric diatomaceous clay, diatomaceous clay, and clayey diatom ooze- is similar in composition to that recovered at the other sites in the transect (see Arthur et al., this volume). Sediment flowed in above about 125 meters sub-bottom (Core 436-14) but is noticeably firmer at 180 meters (Core 436-20). "Biscuits"' occur sporadically below this level to the bottom of Hole 436. The rather arbitrary boundary of lithification or consolidation occurs at about 255 meters sub-bottom, although the sediment remains somewhat soft and easily deformed to the bottom of the hole. This depth of "lithification"' is shallower than at Sites 438 and 439 . This is not surprising, considering that the sediment at Site 436 was deposited much more slowly than at Sites 438 and 439 . Furthermore, deposition was on oceanic crust with higher heat flow and geothermal gradient than that of the continental crust beneath Sites 438 and 439 , and this higher gradient encourages diagenesis of the vitric and biosiliceous components at shallower depths (e.g., Hein et al., 1978).

No healed veins, fractures, or microfaults were observed in cores from Hole 436, even below the onset of lithified sediment. Open fractures are not oriented systematically; most are vertical, splitting the middle of the core, and were probably induced by core-handling (see criteria in Appendix). The sediment at Site 436 has apparently experienced no abnormal stress and was consolidated gradually under the influence of overburden pressure and incipient thermal diagenesis of mineralogically unstable biogenic opal and volcanic glass.

\section{Site 435-Upper Trench Inner Slope}

The muddy diatomaceous ooze at this site is soft and relatively unconsolidated to about 120 meters, where it becomes firmer. However, drilling deformation is high to the bottom of Hole 435A at about 245 meters (lower Pliocene). The sediment is "consolidated" at about 225 meters. At this level in the hole, sections of coherent con- 
solidated material still alternate with relatively unconsolidated and drilling-deformed sediment.

Although it is difficult to discern structure in the cores because of drilling-induced deformation and poor core-face surfaces, with one exception no veins, healed fractures, or faults were noted during our examination of the cores. in Sample 435A-10-1 (225 m on sawed face, lower Pliocene) a 2 to $3 \mathrm{~cm}$ long dark vein or healed fracture was noted. Open fracture systems are not extensive, but a widely spaced hackly parting with slight preferred orientation does occur in some core pieces near the bottom of Hole 435A. The open fractures were probably induced by core-handling. Therefore, either extensive tectonic stress was not communicated to the upper part of the trench axis slope, or the hole was not drilled deep enough to encounter it.

\section{Site 440-Midslope Terrace}

The predominantly diatomaceous muds at Site 440 becomes consolidated at about 175 meters sub-bottom, where they are first cut with a saw (Core 440B-4), but the mudstones remain relatively soft to about 300 meters; consolidation is transitional. "Biscuits"' (Plate 4, Figure 1, and Appendix) are present from about 160 to 340 meters.

Below 385 meters (Core 440B-27) to the bottom of the hole ( 814 meters), the sediment is highly fractured and faulted (Figure 5). The tectonic deformation affected sediment mainly of late Pliocene through late Miocene age. The most intense deformation occurs in lower and upper Pliocene sediment. A few faint vertical veins and fractures occur between 254 and 350 meters (lower Pliostocene-upper Pliocene), but these are sporadic in occurrence and are separated by unfractured zones of sediment. The veins and fractures are inclined from $40^{\circ}$ to vertical. Within this interval bedding dips up to $10^{\circ}$ were recorded, whereas prior to the incidence of fracturing, bedding was essentially horizontal. The intensity of fracturing, as evidenced by healed fractures, is high variable from 380 meters (Core 440B-27) down to about 620 meters depth (Core 440B-51). The sediment is highly fractured below this level to about 725 meters (Core 440B-63) sub-bottom. Cores 440B-67 through 440B-71, at the bottom of the hole, contain some zones of healed fractures, but the overall deformation was apparently less intense in this interval than in the preceding interval.

From about 380 meters to the bottom of the hole, bedding dips are variable but steep, generally between $15^{\circ}$ and $40^{\circ}$. Some of the steeper dips are within zones which have apparently slumped from higher on the slope (mostly in the lower Pliocene). There is no trend toward steadily increasing dips downhole; it is possible that parts of the section have been faulted and tilted or slumped slightly relative to other parts. However, beds of late Pliocene and younger age have not been tilted.

Fractures and microfaults vary somewhat in orientation throughout the section, but apparent dips and rota- tion of core pieces relative to one another have impeded our analyses of possible trends. Most of the fault and fracture planes are inclined between $60^{\circ}$ and $90^{\circ}$ degrees relative to the horizontal. Conjugate fault or fracture sets are prevalent, with angles of $30^{\circ}$ to $45^{\circ}$ between fault planes. The fractures in most intervals are closely spaced, ranging from $0.05 \mathrm{~cm}$ to $2 \mathrm{~cm}$ in separation. Fracture planes are often sinuous and anastomosing (Plate 5, Figure 2). The combination of one or more healed conjugate fracture or fault sets and a very close spacing in some intervals gives the appearance of brecciation. Both normal and reversed senses of offset occur. A slightly dipping layer is often repeatedly offset several millimeters to several centimeters along its interior length by a series of normal or reverse faults (e.g., Plate 5, Figure 3). Most fault and fracture planes are less than $1 \mathrm{~mm}$ wide and contain fine-grained dark clay fillings.

Open fractures in cores range from unsystematic single occurrences to systematic sets of partings which often parallel the healed fractures but do not necessarily break along them. These open fractures are generally not filled by fine-grained material, although it appears that in some cases drilling mud has been injected into them. It is possible that some of the fractures were open at depth in situ, but many of them may have been created during drilling and core-handling. The occurrence and attitudes of these fractures are logged on Figure 5 along with healed fractures, dips of bedding, and core deformation.

Recovery of cored material was 50 per cent, which is a little below the average for that at Sites 438 and 439 ( 55 per cent) but above that for the unfractured Site 435 (44 per cent) and far above that for Sites 441 and 434 . The fractures and faults at Site 440 were rehealed and the sediment more coherent than that at Sites 441 and 434 .

\section{Site 441-Lower Trench Inner Slope}

Recovery of core material at Site 441 was very poor, averaging about 21 per cent. Very little coherent core was obtained. Much of the sediment was recovered in the form of angular chips of about 1-cm diameter (Plate 6, Figure 1).

The diatomaceous vitric muds and silty muds become "lithified" at about 130 meters sub-bottom, although because recovery was poor in cores from shallower depths, the sediment may have been indurated as shallow as 100 meters sub-bottom. Healed fractures and dark anastomosing veins first occur at about 260 meters sub-bottom in upper Pliocene diatomaceous claystone (Cores 441-9 and 441A-H-1). Most fractures, however, are open and not characterized by dark fillings of finegrained clayey material (Plate 6, Figure 3 ). Both open and healed fractures are planar and dip from $40^{\circ}$ to $60^{\circ}$ to horizontal. The open fractures (or hackly parting) most often parallel trends of healed fractures. Visible 
offsets, along many closely spaced microfaults (both normal and reverse), range from $1 \mathrm{~mm}$ to about $2 \mathrm{~cm}$. Many of the fracture or microfault sets appear to be orthogonal to one another. Some of the core has been intensely brecciated (Plate 10, Figures 1 and 2), but little relative movement of clasts has occurred.

Although many open fractures are not filled by finegrained material, they may have been held open in situ by fluids. Moore (this volume) has discussed the grooves or steps (see Plate 12) on surfaces of open fractures at Site 441 which he believes are slickensides related to movement along the open fractures. He suggests that the open fracture systems were formed at depth in the sediment and that most of them did not result from the drilling or core-handling. The very poor recovery may be related to the presence of these closely spaced and largely unhealed fracture systems.

Bedding dips vary irregularly and somewhat unsystematically downhole, ranging from horizontal in the upper part of the hole to $35^{\circ}$ and locally $70^{\circ}$ at depth. There is no evidence for repetition of sedimentary units or biostratigraphic zones at Site 441. Seismic reflection records (Figure 2) suggest that the sediments recovered represent a largely subhorizontal slope sequence of late Miocene to Pleistocene age. The sediment is highly fractured, characterized by both open and healed systems. Only upper Pliocene and older sediment is lithified and fractured. Much of the Pleistocene record has apparently been removed or was not deposited at this site.

\section{Site 434-Lower Trench Inner Slope}

Recovery of core at Site 434, drilled to 637.5 meters, was less than 20 per cent. Nonetheless, the sediment recovered affords a fair record of trends in tectonic deformation downhole. Sediment is "lithified" or indurated at about 101 meters and is very firm at 130 meters subbottom depth. The first dark veins and healed fractures visible in the cores occur at 250 meters depth (Core 434-28). However, the sediment is broken into small chips by coring as shallow as 70 meters, and systematic open fracture sets occur in cores from about 150 meters depth. The healed fractures and veins occur in Pliocene and older sediment. Much of the Pleistocene sedimentary record is missing, as at Site 441 . Bedding inclinations vary somewhat unsystematically downhole from horizontal to about $30^{\circ}$.

As at Site 441 , open fracture sets commonly parallel or open along healed fractures. However, many open fractures occur in cores which contain no veins or healed fractures (e.g., Plate 7, Figure 3). Some of these fractures may have been opened during drilling or corehandling and parallel a slight foliation of diatoms in the diatomaceous claystones. The phenomenon of preferred orientation of planar or elongate particles in the mudstones at Site 434 is relatively uncommon. Diatom frustules, for example, tend to retain a somewhat random orientation (probably originating from burrowing) even when relatively highly compacted (e.g., Plate 9 , Figures 4 and 5). However, at depths greater than 600 meters, bedding-parallel fabrics are more common and collapse of diatoms oriented vertically can be observed (Plate 9, Figure 2, and Arthur et al., this volume, Figure 14). Surfaces of some open fractures are marked by grooves and steps which may have originated during movement along them or may be related to oblique intersections with other fractures (Plate 8, Figure 2). We cannot determine from relationships in the core whether or not the fractures were open in situ.

Veins and healed fractures are ubiquitous in cored material from below 250 meters. However, not all sediment is highly fractured. Relatively unfractured zones on the order of 10 to $50 \mathrm{~cm}$ thick alternate with nearly brecciated intervals. Microfaults dipping from $30^{\circ}$ to $70^{\circ}$ to the horizontal are common, and offsets along both normal and reverse faults up to $15 \mathrm{~cm}$ were noted (Plate 7, Figure 1). Fault or fracture sets of more than one orientation commonly cut one another. The core often appears brecciated and rehealed without major offset on crosscutting sets of closely spaced en echelon fractures. More calcareous intervals have calcite-cemented fractures, some of which still retain substantial fracture porosity (Plate 7, Figure 4). Tectonic deformation for the most part appears to have occurred after induration of the sediment. Most fracture planes are sharp, breccia clasts angular, and there is little evidence of soft sediment deformation. In a few intervals there are stretched and smeared burrows, which may be due to downslope movement of sediment after deposition or shearing of soft sediment during tectonic deformation.

Microscopic and SEM examination of sediment from Site 434 revealed the following:

1) Fracture and microfault planes are usually less than $0.5 \mathrm{~mm}$ thick. They are filled with finely comminuted quartz and clay minerals (Plate 12, Figure 3 ) as well as pyrite and calcite in some intervals. The clay mineral assemblage in fractures, typically montmorillonite, illite, and minor chlorite, was similar to that of the surrounding sediment in all cases. The dark color of fracture and vein fillings is apparently due to the very fine grain size.

2) Fractures and microfaults apparently formed in semilithified or indurated sediment. Grain breakage occurs along them (Plate 11). Elongate or platy grains are reoriented (Plate 11) so that their long axes run parallel to the orientation of the fracture plans. This suggests some relative movement, enough to cause grain breakage and reorientation, even along fractures exhibiting no visible macroscopic offset. Some grain orientation and the filling of fine-grained (predominantly $<2 \mu$ ) material may have been due to fluids migrating upward along partly open fractures. At least some fractures were open in situ because they are now filled by sparry calcite cement (e.g., Plate 10, Figures 1 and 2).

3) Fractures and microfaults apparently formed in sediment of relatively high water content which was not highly compacted. Little preferred orientation of diatom frustules was noted either relative to a vertical stress field or in any direction related to fractures (see Plates 9 and 11). However, flat diatom frustules at the margins of fractures are commonly rotated into the plane of the fracture (Plate 13, Figure 1). 


\section{DISCUSSION AND COMPARISON OF SITES}

1) The Neogene sediment at all sites from the deep sea terrace, slope, and oceanic plate consists primarily of terrigenous mud with admixtures of diatoms and volcanic ash. Variation in rates of accumulation of terrigenous minerals, diatoms, and ash as well as in diatom and ash content are observed downhole at all sites (see Arthur et al., this volume). The upper parts of the reference sites on the deep sea terrace and on the oceanic plate have somewhat higher overall diatom content than sediments on the trench inner slope. Nonetheless, upper Miocene through Pliocene sediment from all sites is remarkably homogeneous and similar across the transect.

2) Trends in lithification at the reference sites are distinctly different from those of the trench inner slope sites; recall that, as a first approximation, lithification is defined as the difference between "sediment," cut by a cheese-slicer, and "rock," which must be cut with a power saw (e.g., Moberly, 1971). At the trench inner slope sites, the sediment is lithified at very shallow depths (Figure 6: $175 \mathrm{~m}$ at Site 440, approx. $130 \mathrm{~m}$ at Site 441, and $101 \mathrm{~m}$ at Site 434) compared to that in reference sections at Sites 438 and $439(420 \mathrm{~m})$ or Site 436 $(255 \mathrm{~m})$. The age of the first lithified sediment is upper Miocene at Sites 438, 439, and 436, lower Pleistocene at Site 440, and upper Pliocene at Site 441 and 434. Clearly, the lithification or consolidation is not solely a function of age or depth of burial.

3) The physical properties are distinctly different between sediments from trench inner slope sites and the reference sites.

Sediment in the upper 400 meters of all sites on the trench inner slope appears overconsolidated relative to a standard curve void ratio versus overburden pressure calculated from the physical properties data from Sites 438,439 , and 436 (see next section and Figure 8). However, all trench inner slope sites show a normal increase in density (decreasing void ration) down to about 250 meters (or $13 \mathrm{Kg} / \mathrm{cm}^{2}$ overburden pressure), where they show a sudden anomalous decrease. The density then remains essentially constant to 450 meters. Below 450 meters $(20 \mathrm{Kg} / \mathrm{cm}$ overburden pressure) at Sites 440 and 441 , the density falls at or below that of the standard reference section but generally increases again downhole. At Site 434, however, higher densities continue to the bottom of the Site at 637 meters. Thus there is a significant reversal in the trend of density increase (porosity reduction) at all trench inner slope sites in the interval from about 250 meters to 400 meters. From about 400 meters to nearly 500 meters at Sites 441 and 434 and about 600 meters at Site 440, the bulk density either continues to decrease slightly (or porosity increases) or remains the same. These trends are clearly anomalous, and we cannot explain them either by major changes in lithology or grain density.

4) Dark veins and healed fractures and faults occur at all sites except Sites 435 and 436 . The onset of these closed and rehealed structures occurs at much shallower depths in sites on the trench inner slope than on the deep sea terrace. The first such structures identified occur at 603 meters at Sites 438 and 439, at 254 meters at Site 440 , at 252 meters at Site 441 , and at 255 meters at Site 434 (Figure 6). These fractures occur at depths below the "lithification front" in each hole. Healed fractures or veins may have occurred at shallower depths at Sites 434 and 441 , but because of poor core recovery they are difficult to recognize. The fractures and faults demonstrate brittle deformation. Faults exhibit normal and reverse offset, but most show generally less than $10-\mathrm{cm}$ displacement. Conjugate sets are often present. No fractures, faults, or veins occur in sediment younger than upper Pliocene.

Pervasive open fractures occur in trench inner slope cores as well but are not common at Sites 438, 439, and 436. It is difficult to establish that these open fracture or joint systems are primary features-that is, not produced by drilling or core-handling. However, the correlation of zones of highly fractured and faulted material with systems of open fractures and generally poor core recovery suggests that open fractures may exist in situ. No offset was noted on any open fractures, but the fracture planes often parallel those of rehealed fractures or faults in the same core. Two main possibilities exist: (1) the stress of drilling and release of pressure induces fracturing - the fractures often open along a preferred orientation related to an existing fabric; or (2) the fractures are already open and filled with fluids in situ.

The correlation of zones of open fractures or joints in cores with reversals in the density gradient downhole also suggests that the fractures are open in situ. In fact, the occurrence of the anomalous density interval may indicate a zone of fluid overpressures within the fractured section. Moore (this volume) has also argued that the open fractures are primary, based on a study of faintly slickensided fracture planes. In the highly fractured intervals at Sites 441 and 434, drilling often breaks the sediment into small $(<1-\mathrm{cm})$ chips. Core recovery is poor in these zones.

There are several problems which make this analysis less than certain.

1) Sediment at Site 440 on the midslope terrace may have been affected by one or more periods of downslope movement of the entire sediment mass in the prePleistocene (see Site 440 Site Chapter). This could have contributed to some deformation of sediment recovered at that site.

2) At Site 434 (Figure 2) drilling may have penetrated accreted sediment (see Site 434 Site Chapter) which could account for the more highly consolidated samples recovered below 400 meters in comparison to those at adjacent Site 441 . The accreted sediments would be expected to be more highly consolidated. However, the lack of downhole logs at Site 434 may prevent adequate comparison to Sites 440 and 441 .

3) A third problem lies in the location of Sites 441 and 434 on the trench lower slope (Figure 2). Part of the multichannel seismic record (JNOC Line 2) on which the sites are located (Figure 2) was apparently shot down the axis of a submarine canyon or narrow slump scar. A 


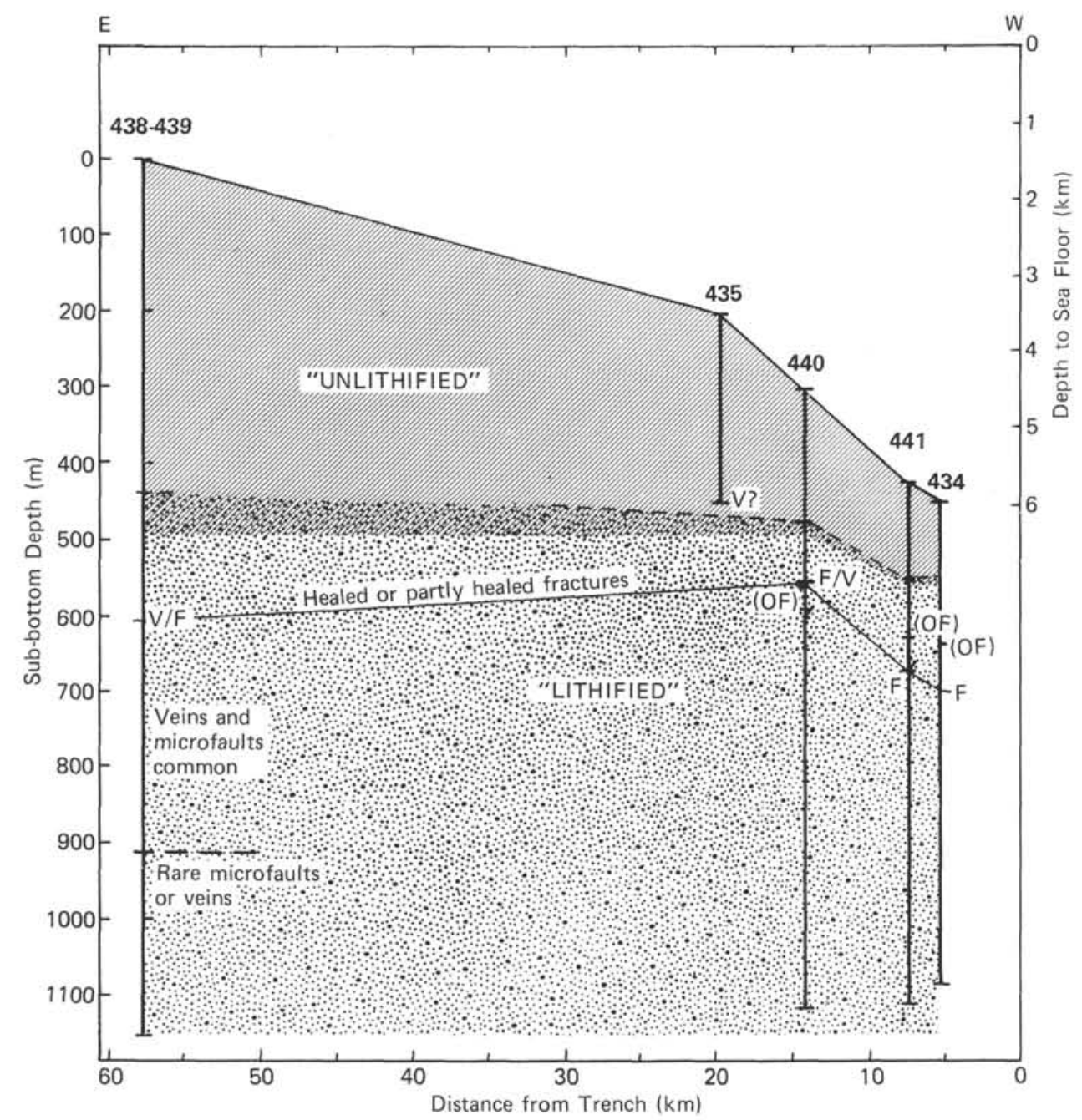

Figure 6. Schematic diagram showing depth to lithified or indurated sediment in drill sites across the Japan fore-arc region and the first occurrence of healed veins (V) and fractures (F) and open fractures (OF). Note the occurrences of open fractures at or above that of healed veins and fractures at Sites 434 and 441 and the general shoaling of the "lithification front" and first occurrence of veins and fractures toward the trench.

crossline at Site 441 (JNOC Line C) shows this feature (Figure 7). Pleistocene hiatuses are present at both sites. It is possible that as much as 450 meters of upper Pliocene-Pleistocene sediment was removed by erosion or slumping in the area where the holes were drilled. Although this much section can be interpreted to lie on adjacent hills stratigraphically above the level of the sites, the interpretation is very uncertain. Another estimate of the amount of missing section can be made by extrapolating Pliocene sedimentation rates (e.g., $175 \mathrm{~m} / \mathrm{m}$.y. for Site 441) through the Pleistocene. This method gives about 315 meters of missing sediment. Therefore the inferred anomalous shallow levels of lithification, consolidation, and fracturing at Sites 441 and 434 may be influenced by the removal of up to 450 meters of overburden. However, this possibility explains neither the anomalous pattterns in density or void ratio observed downhole at these sites nor the great similarity in physical properties, beginning of lithification, and fracture at Site 440 , where no missing section occurs.
Tectonic deformation of the sediment on the trench inner slope may have occurred during a period of increased tectonism rather than as a steady state process. The latest of these tectonic events may have occurred during the late Pliocene, since younger sediment is not faulted or fractured. The possible missing Pleistocene section at Sites 441 and 434 may either have slumped off the slope after deposition because of the earlier development of fractures and overpressured conditions at depth or never have been deposited because of an oversteepening of the slope in the late Pliocene. Arthur et al. (this volume) have presented evidence for a late Pliocene tectonic event which caused significant changes in morphotectonic features and patterns of sedimentation in the fore-arc region off northern Honshu.

\section{LITHOSTATIC VERSUS TECTONIC DEWATERING}

Normal lithostatic consolidation on the Japan margin is inferred from bulk density profiles at Sites 438 , 


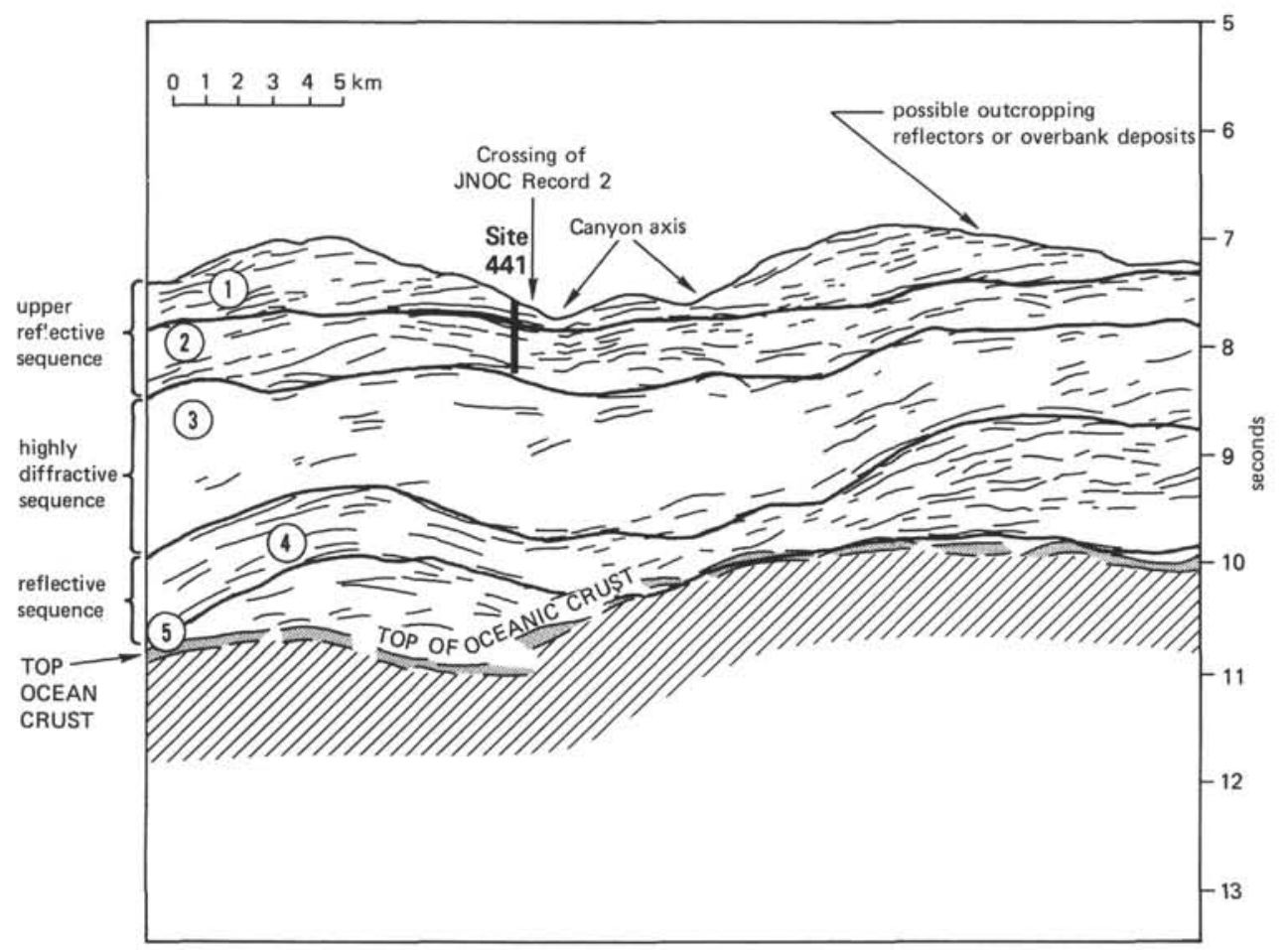

Figure 7. Sketch of JNOC Cross Line C parallel to slope; note location of JNOC Line 2 shown in Figure 2. (1) Constructional levees related to slope canyon with axis near Site 441, or possibly remaining original Pleistocene section eroded or slumped from canyon. About $0.5 \mathrm{~s}$ of sequence in the seismic record represents 450 meters or so of sediment. (2) Pliocene and upper Miocene reflective sequence, still part of slope sediment veneer. (3) Upper Miocene and older landward-dipping sequence, possibly representing subduction accreted sediment. (4) Reflective sequence, possibly pelagic sediments lying above Reflector. (5) Reflections from top of oceanic crust.

439 , and 436 , which lie outside the zone of "accretion." The "standard bulk density profile" (Figure 4) generated from data at these sites has been converted to a standard sedimentation compression (void ratio, $e$-lithostatic pressure, $p$ ) profile (Figure 8 ) which details the "normal" consolidation response of the diatomaceous clays that dominate in this region. This profile exhibits void ratios ( $e$, volume of voids/volume of particles) which decline from 3.1 at 0 to $5.5 \mathrm{Kg} / \mathrm{cm}^{2}$ to 1.4 at 43 $\mathrm{Kg} / \mathrm{cm}^{2}$. Sites 438 and 439 void ratios are also plotted in Figure 8 to indicate the degree of variability associated with textural and compositional variations. Comparison of this standard profile with the generalized curves from Hamilton (1976) indicates that with the exception of near-surface sediments $\left(\leq 6.0 \mathrm{Kg} / \mathrm{cm}^{2}, \leq 180 \mathrm{~m}\right)$, the Japan margin deposits are underconsolidated relative to both pelagic clay and diatomaceous ooze (Figure 8). The cause of this underconsolidation is unknown. Nevertheless, the standard profile can be used as a reference section to define the effect of lithostatic loading in this area because of the similar composition of sediment at other sites.

In contrast to the regular decline in void ratio exhibited by the standard profiles, Sites 440,441 , and 434 show a complex response to loading (Figure 8). All three sites possess a normal dewatering pattern (decreasing void ratio with increasing pressure) at pressures less than $130 \mathrm{Kg} / \mathrm{cm}^{2}$, although the void ratios are significantly smaller (approximately 1.55-2.40) than comparable values defined by the standard curve. These data indicate that sediments in the upper portion $(<130$ $\mathrm{Kg} / \mathrm{cm}^{2}, \leq 230-270 \mathrm{~m}$ ) of each hole are overconsolidated relative to the reference section (Figure 8), if not to pelagic sediments in general (Figure 8, Line C). The degree of overconsolidation is considerable: all three sites show a minimum void ratio of $\sim 1.55$ at 130 $\mathrm{Kg} / \mathrm{cm}^{2}$ (230-270 m depth), whereas a similar void ratio is not encountered in the reference section above 400 $\mathrm{Kg} / \mathrm{cm}^{2}$, equivalent to a burial depth of 855 meters.

Below 230 to 270 meters $\left(>130 \mathrm{Kg} / \mathrm{cm}^{2}\right)$ the void ratio increases with increasing pressure (to 1.67 at 23.8 $\mathrm{Kg} / \mathrm{cm}$, Site 434 ; to 2.27 at $20.8 \mathrm{Kg} / \mathrm{cm}^{2}$, Site 441 ; to 2.45 at $30.4 \mathrm{Kg} / \mathrm{cm}$, Site 440 ), reflecting the decline in bulk density with depth (Figure A,1). Although this pattern is abnormal, its occurrence is widely recognized in sediments characterized by excess (i.e., superhydrostatic) pore pressures (Fertl, 1976). This is not to imply that the presence of abnormal fluid pressures has been established in these Japan trench slope sediments; although the density distribution is characteristic of overpres- 


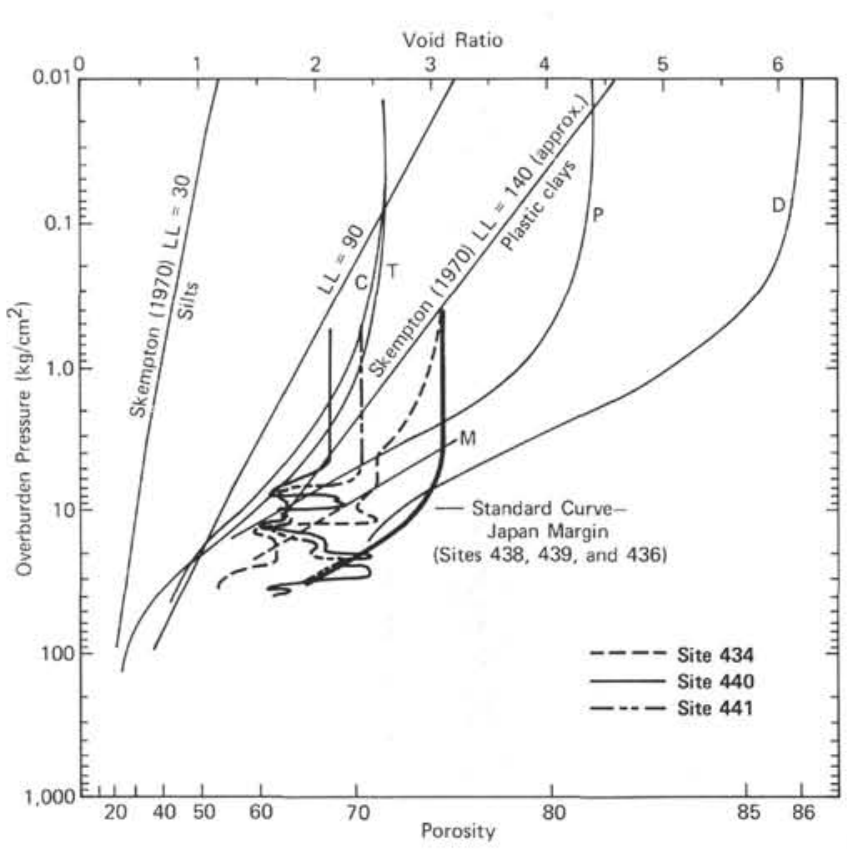

Figure 8. Void ratio and porosity versus pressure Plots for various general types of marine sediments from Hamilton (1976) and Skempton (1970). D = diatomaceous ooze, $\mathrm{C}=$ calcerous sediment, $\mathrm{P}=$ pelagic clay, $\mathrm{T}=$ terrigenous sediment, $\mathrm{M}=$ field consolidation curve derived from the experimental Mohole.

sured sediments, the in situ velocity log (Site 440) gives no indication of abnormally low velocities, which are commonly taken to be more reliable indicators of overpressured zones. Nevertheless, the possibility of surpressures deserves consideration.

The downhole increase in void ratios (Figure 8) in the middle portion of each site occurs within the veined and fractured zone. This pattern suggests development of a secondary "fracture porosity" rather than a change in interstitial volume. The fact that minimum void ratios $(\sim 1.55)$ in each hole occur at $130 \mathrm{Kg} / \mathrm{cm}^{2}$ suggests that fracturing does not occur at lower overburden pressures, presumably because the sediments have not consolidated sufficiently to undergo brittle failure.

Direct observation and physical properties, then, suggest that these sites are characterized by an unfractured upper portion $(\leq 270 \mathrm{~m})$ which overlies a brecciated lower column. It is possible that the unfractured sediments form a low permeability "cap" over the brecciated zone which restricts fluid communication to the surface. In such a circumstance, abnormal pore pressures might be anticipated.

At pressures greater than about 200 (Site 441) to 300 (Site 440$) \mathrm{Kg} / \mathrm{cm}^{2}$, void ratios at Sites 441 and 440 take on values which approximate the standard profile. Consolidation appears to be normal (i.e., lithostatic), and fractures observed in cross section are apparently closed by overburden pressure.

Site 434 void ratios, at pressures greater than 130 $\mathrm{Kg} / \mathrm{cm}^{2}$, are considerably lower than at all other sites.
The sediments are uniformly overconsolidated relative to the reference section (Figure 8). Void ratios as low as 1.2 are encountered at $31.0 \mathrm{Kg} / \mathrm{cm}^{2}(540 \mathrm{~m})$. Similar values, based up extrapolation of the reference section, should occur at $47.5 \mathrm{Kg} / \mathrm{cm}^{2}(1010 \mathrm{~m})$ under lithostatic load alone.

The general pattern of consolidation, as defined by physical properties, is complex. Clearly, Sites 440 and 441 are overconsolidated above 400 meters $(\leq 200$ $\mathrm{Kg} / \mathrm{cm}^{2}$ ). It is not obvious, however, that the dewatering has been tectonically induced. Because consolidation at greater depths appears to be normal, dewatering at Site 434 can be attributed either to tectonic overpressures, since the entire section is overconsolidated, or, in the case of Site 441, to previous burial, if in fact slumping has removed up to 45 meters of overburden.

Unlike sediments from other convergent margins (Aleutian trench slope, Lee et al., 1973; Nankai trough slope, Trabant et al., 1975; Washington-Oregon slope, Carson, 1977), Japan Trench slope deposits are not highly overconsolidated (maximum inferred overpressure $=28 \mathrm{Kg} / \mathrm{cm}^{2}$, Site $434,270 \mathrm{~m}$ ). This lack of severe overconsolidation, however, may be attributed to the fact that the Japan Trench slope sediments have not been scraped off the oceanic plate but are "normal" continental slope deposits which apparently cover the zone of active accretion. The data do indicate, however, that these normal slope deposits are modified (overconsolidated and brecciated) by the subduction-accretion process.

Despite their singularity, the Japan Trench sediments are similar to other convergent margin deposits in that they exhibit a fissile nature, hackly parting, and/or rudimentary cleavage. Indeed, the physical properties data suggest that from about 220 to 550 meters (130-300 $\mathrm{Kg} / \mathrm{cm}^{2}$ ) secondary fracturing or parting controls bulk density and porosity and, by implication, may control permeability. If this is the case, then the development of veins, parting planes, and/or fractures probably governs the rate of dewatering in the sediments of the subduction complex.

We propose the following model for the development of the fractured rock on the Japan Trench inner slope (Figure 9). The hemipelagic sediment initially dewaters through pressure-induced anastomosing veins which propagate preferentially in a direction favorable to the ambient stress field. The veins, being lubricated planes of weakness, become convenient planes of strain release that evolve into a series of closely spaced joints and microfaults. If the permeability is insufficient to allow free upward migration of fluids, the microfractures are opened and secondary porosity results. As long as fluid pressure exceeds the force of the ambient stress field, the fractures are held open. Overpressuring develops as a resistance to upward migration increases and may reach the point where clasts essentially become fluidsupported. In order to maintain the overpressured conditions, or to establish them in the first place, a veneer of relatively impermeable mud must be rapidly deposited above the deforming mass. Nagumo et al. 


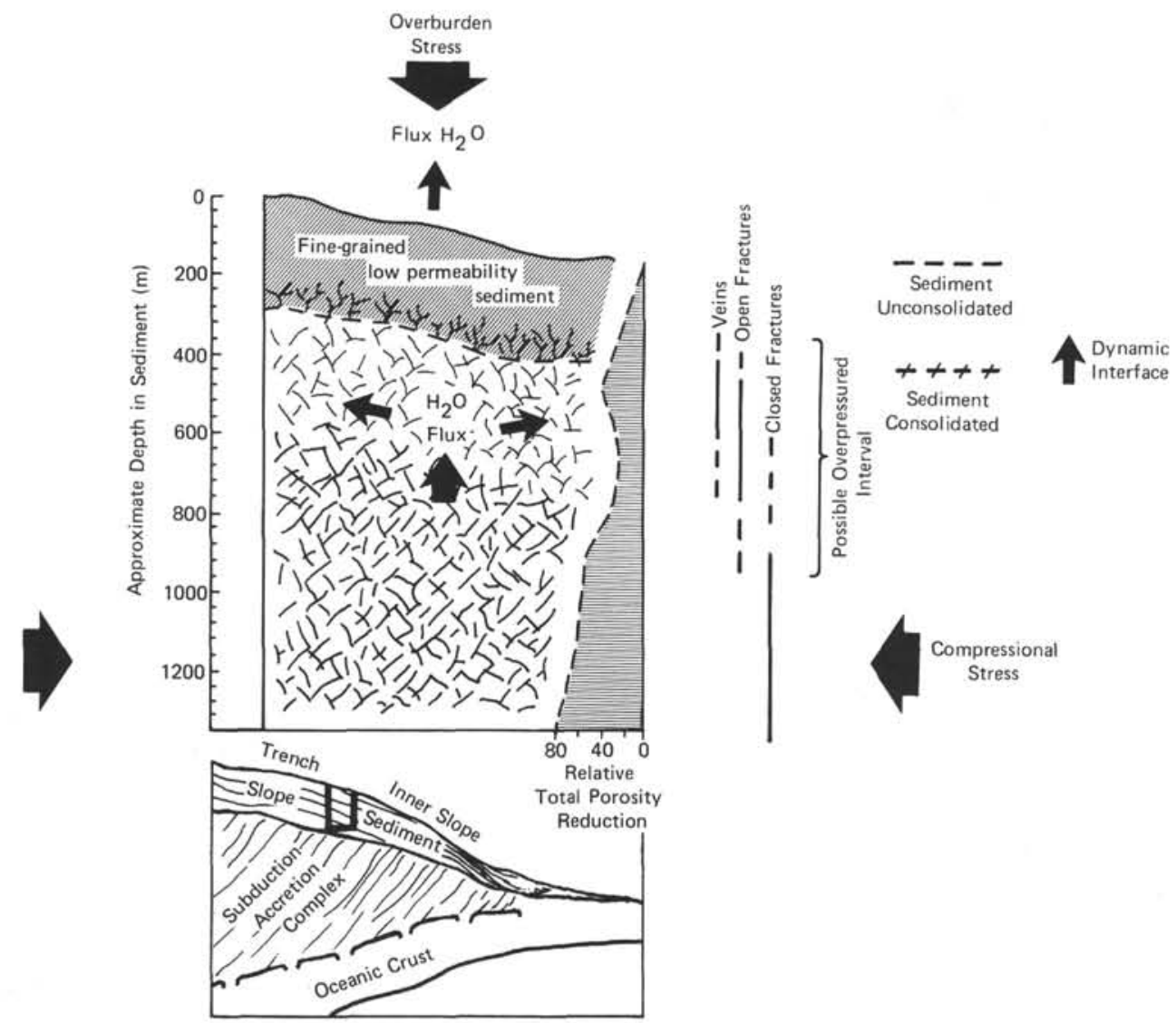

Figure 9. Schematic model for sediment dewatering, porosity reduction, and stages of tectonic deformation related to depth burial on the trench inner slope off northern Honshu. Fractures at an intermediate stage may be held open by excess fluid pressure caused by tectonic dewatering of sediment at depth and upward migration of fluids along a fracture network. Greater lithostatic stress with burial to depths greater than 500 meters causes closing and rehealing of fractures.

(this volume) have presented evidence from seismic refraction measurements that supports our contention that much of the sediment under the trench inner slope is water-charged and that open, water-filled fractures may be present. Low seismic velocities of $3.0 \mathrm{~km} / \mathrm{s}$ or less (Murauchi and Ludwig, this volume) and a low shear wave/compressional wave velocity ratio leading to a high Poisson's ratio indicate the fluid nature of much of the trench inner slope wedge.

Such overpressured zones may locally reduce the shear strength of the sediment and, analogous to settings along the Gulf Coast (e.g., Booth, 1979), promote downslope mass movement on the trench inner slope. The actual slope angle required for initiation of slumping would be relatively low (i.e., possibly less than 1 degree). Large sediment masses at the "toe" of the slope along the trench (JNOC Lines 1 and 2), interpreted as slump deposits (Arthur et al. and Nasu et al., both this volume) may have originated in this manner. These masses may consist partly of mixtures of angular chips and slabs of older consolidated sediment set in a younger unconsolidated matrix, similar to some slump breccias found in Site 441 cores.

\section{CONCLUSIONS}

Our study was made difficult by poor core recovery at Sites 441 and 434, and this lack of recovery is in itself indicative of a significantly different deformational setting. The downhole geophysical logs in combination with shipboard physical properties measurements, visual observations of cores, and petrographic studies were instrumental in helping to elucidate the details of consolidation and deformation, especially where recovery was poor.

Fractures and faults in slope sediments deposited on the trench inner slope may be related to tectonic stress associated with plate convergence at the Japan Trench. Judging by the style and intensity of deformation in cores at Sites 438 and 439 , the Neogene sedimentary sequence on the deep sea terrace is little affected by the stresses related to plate convergence. Seismic records across the terrace reveal only broad folds and steep faults. This structural style extends seaward perhaps as far as the midslope terrace on the trench inner slope.

The cores from sites on the trench inner slope from the midslope terrace seaward (Sites 440, 441, and 434) 
have a brecciated appearance. The sediment is more deformed, the deformation extends higher in the sequence, and lithification is more advanced at shallow levels than on the deep sea terrace. This greater deformation, which is evidenced by anomalous physical properties, poor core recovery, and pervasive joints or open fracture networks, suggests a greater communication of stress from plate convergence to sediment within the trench inner slope wedge than elsewhere across the margin.

This explanation is generally consistent with present models for the deformation of sediment and structure at the leading edge of a convergent margin (Karig, 1973; G. F. Moore and Karig, 1976; Karig and Sharman, 1975; Karig et al., 1979; Seely and Dickinson, 1979) with the following exceptions. First, the sites drilled on the Japan Trench Transect penetrated mainly a thick slope sediment sequence. Only at Site 434 is there evidence for recovery of possible subduction accreted sediment within a sequence of steeper landward-dipping reflectors beneath the subhorizontal slope sediments. Apparently the slope sediment veneer also becomes involved in deformation along the Japan margin, through initial tectonic consolidation and dewatering followed by one or more episodes of faulting and brittle fracture. Therefore the structural transition from slope sediment to accreted sediment may not be a sharp one, in contrast to the model proposed by G. F. Moore and Karig (1976). Secondly, along the Japan Trench margin off northern Honshu, the stress of convergence appears to be communicated mainly to the region of the lower trench inner slope. The midslope terrace may occupy a position of discontinuity, landward of which little deformation, related directly to convergence, occurs.

The intensity of tectonism at the Japanese convergent margin may have varied periodically; steady state deformation cannot be assumed, particularly on a local scale, since the deformation has not seriously affected Pleistocene sediment and there is evidence of a major tectonic change in the late Pliocene along the margin off northern Honshu. A period of intense deformation may have occurred during the late Pliocene.

The possible presence of fractured, overpressured zones at depths between 200 and 500 meters under the trench inner slope may provide a zone of low shear strength along which there is widespread mass movement of sediment on the slope.

\section{ACKNOWLEDGMENTS}

We have benefited from discussions with Ed Buetner, E. L. Hamilton, J. Casey Moore, and George Moore. Larry Byers, Tom Fouch, and J. Casey Moore reviewed the manuscript in draft; we thank them for their comments and criticism.

\section{REFERENCES}

Booth, J. S., 1979. Recent history of mass-wasting on the upper continental slopes, northern Gulf of Mexico, as interpreted from the consolidation states of the sediment. In Doyle, L. J., and Pilkey, O. H., Jr. (Eds.), Geology of
Continental Slopes: Soc. Econ. Paleont. Mineral. Spec. Publ. No. 27, pp. 153-164.

Carson, B., 1977. Tectonically induced deformation of deep sea sediments off Washington and northern Oregon: Mechanical consolidation. Mar. Geol., 24, 289-307.

Fertl, W. H., 1976. Abnormal Formation Pressures; Implications to Exploration, Drilling, and Production of Oil and Gas Resources: Developments in Petroleum Science 2: Amsterdam (Elsevier).

Gealy, E. L., Winterer, E. L., and Moberly, R., 1971. Methods, conventions and general observations. In Winterer, E. L., Riedel, W. R., et al., Init. Repts. DSDP, 7, Pt. 2: Washington (U.S. Govt. Printing Office), 9-26.

Hafner, W., 1951. Stress distributions and faulting. Geol. Soc. Am. Bull., 62, 373-398.

Hamilton, E. L., 1976. Variations of density and porosity with depth in deep-sea sediments. J. Sediment. Petrol., 46(2), 280-300.

Hein, J. R., Scholl, D. W., Barron, J. A., Jones, M. G., and Miller, J., 1978. Diagenesis of Late Cenozoic diatomaceous deposits and formation of the bottom simulating reflector in the southern Bering Sea. Sedimentology, 25, 155-181.

Honza, E., Kagami, H., and Nasu N., 1977. Neogene geological history of the Tohoku Island Arc System. J. Ocean. Soc. Jpn., 33, 297-310.

Hubbert, M. K., 1951. Mechanical basis for certain familiar geologic structures. Geol. Soc. Am. Bull., 62, 355-372.

Karig, D. E., 1973. Plate convergence between the Philippines and the Ryukyu Islands. Mar. Geol., 14, 153-168.

Karig, D. E., and Sharman, G. F., III, 1975. Subduction and accretion in trenches. Geol. Soc. Am. Bull., 86, 377-389.

Karig, D. E., Suparka, S., Moore, G. F., and Hehanussa, P. E., 1979. Structure and Cenozoic evolution of the Sunda Arc in the Central Sumatra region. In Watkins, J. S., Montadert, L., and Dickerson, P. W. (Eds.), Geological and Geophysical Investigations of Continental Margins: Am. Assoc. Petrol. Geol. Mem. No. 29, pp. 223-238.

Lee, H. J.,Olsen, J. W., and von Huene, R., 1973. Physical properties of deformed sediments from Site 181. In Kulm, L. D., von Huene, R., et al., Init. Repts. DSDP, 18: Washington (U.S. Govt. Printing Office), 897-901.

Minster, J. B., Jordan, T. H., Molnar, P., and Haines, E., 1974. Numerical modelling of instantaneous plate tectonics. R. Astron. Soc. Geophys. J., 36, 541-576.

Moore, G. F., and Karig, D. E., 1976. Development of sedimentary basins on the lower trench slope. Geology, 4, 693-697.

Moore, J. C., and Karig, D. E., 1976. Sedimentology, structural geology, and tectonics of the Shikoku subduction zone, southeastern Japan. Geol. Soc. Am. Bull., 87, 12591268.

Richards, A. F., Hirst, T. J., and Parks, J. M., 1974. Bulk density-water content relationship in marine silts and clays. J. Sediment. Petrol., 44(4), 1004-1009.

Seely, D. R., and Dickinson, W. R., 1979. Structure and stratigraphy of forearc regions. Am. Assoc. Petrol. Geol. Bull., 63, 1-31.

Seely, D. R., Vail, P. R., and Walton, G. G., 1974. Trench slope model. In Burk, C. A., and Drake, C. L. (Eds.), The Geology of Continental Margins: New York (Springer-Verlag), pp. 249-260.

Skempton, A. W., 1970. The consolidation of clays by gravitational compactation. Q. J. Geol. Soc. London, 125, 373412. 
Trabant, P. K., Bryant, W.R., and Bouma, A. H., 1975. Consolidation characteristics of sediments from Leg 31 of the Deep Sea Drilling Project. In Karig, D. E., Ingle, J. C., Jr., et al., Init. Repts. DSDP, 31: Washington (U.S. Govt. Printing Office), 569-572.

\section{APPENDIX \\ DEFORMATION IN DSDP CORES - ORIGINAL OR DRILL-INDUCED?}

Drilling produces stresses that result in deformation of the core material. Downward force from drilling produces stresses parallel to the core axis; rotation of the bit produces radial stresses symmetrical about the core center. Despite a bearing designed to isolate the core barrel from rotation, there commonly appears to be an undetermined amount of radial stress applied to the core as it enters the inner core barrel. When the material being cored is plastic, it deforms by macroscopic flow; when the material is brittle, it deforms by fracture with associated zones of sheared material which can become mobile and flow plastically. The overprint of drill-induced deformation on original deformation is often very difficult to isolate. Commonly the approach onboard the Challenger is to identify obvious and suspected drill disturbance and attribute the remaining deformation to natural causes. In addition, it is helpful to compare cores from an area with little tectonism to cores from areas whose seismic records show faulting and folding. Generally there is a certain amount of subjective judgment in ascribing an origin to deformation that falls between obvious drill-induced deformation and obvious natural deformation.

Drilling-induced deformation is generally recognized from an orientation of features that is symmetrical to the core. Symmetrical plastic deformational features induced by drilling include the following:

1) a zone of flowage along and subparallel to the core liner;

2) bending or hooking of horizontal beds in the direction of core penetration with tails along the core liner;

3) tight swirls that contrast with the general lesser intensity of core deformation, sometimes encountered when seas are rough enough to give the drill string a pumping action. These swirls have axes that may trend in a circular pattern.
4) sections of disturbed material are softer and more watery than the rest of the core and sometimes contain randomly oriented drill cuttings. Such sections may grade into obvious drill slurry.

Symmetry diagnostic of drilling-induced fracture occurs as sediment lithifies. The following are some commonly observed types of drilling-induced fractures.

1) horizontal disk fractures that sometimes develop circular striations on a polished surface. Such fractures develop as lithification increases, but not beyond the point at which the material can be readily cut with a wire. These fractures divide the core into short (about $5-\mathrm{cm}$ ) segments and result in the biscuit structure (also called "Challengerite structure"). Biscuits are generally of uniform length, separated by disturbed or sheared material up to $1 \mathrm{~cm}$ thick marking the horizontal disk fractures. Toward the core liner, these fractures and their associated gouge zones hook both up- and downcore.

2) fractures originating near the core center, especially those with a radial symmetry in the downcore direction;

3 ) vertical centerline fractures that become more obvious as the core dries.

Natural fracture generally lacks both rotational symmetry and symmetry consistently related to the core axis. The following are features diagnostic of natural fracture.

1) fractures with polished and slickensided faces and without radial symmetry;

2) healed fractures, especially those filled with secondary minerals;

3 ) fractures that extend across the core with no obvious relation to the core liner, especially those with high inclinations. These are commonly observed in conjugate sets.

Natural fractures that are open in the laboratory may not necessarily have been open in situ. Fractures would be expected to open as core is cut, as lithostatic pressure is released, and as core is handled. Thus incipient fractures in situ may appear as open fractures in the core. In situ open fracturing is difficult to establish and can be inferred from detection of fracture porosity or from washouts shown by the caliper $\log$ in zones where fractured core has been recovered.

The most certain evidence of fracturing comes from healed fractures. When a core contains parallel healed and open fractures of the same character, the open fractures are likely to be opened original fractures. Thin section examination of fractures can indicate reorientation of mineral grains or deposition of secondary minerals. 

PLATE 1

Incipient Veins and Fractures on the Deep Sea Terrace

Figure 1 Sample 438A-59-1, 89-98 cm (613 m sub-bottom): The highest occurrence of incipient veins at this site showing initial stage of development. Sulfides are concentrated within the veins.

Figure 2 Sample 438A-60-1, 3-13 cm (62 m sub-bottom): Veins are in a slightly later stage of development than those in Figure 1. Note dark color of vein filling and discontinuous development. All are oriented vertically, suggesting upward migration of fluids.

Figure 3 Sample 438A-65-4, 3-13 cm (674 m sub-bottom): An advanced stage of vein development associated with beginning of fracturing. Note greater parallelism of fracture sets and characteristic diagonal orientation in comparison to Figures 1 and 2.

Figure 4 Sample 438A-66-2, 40-60 cm (680 m sub-bottom): A cemented limestone breccia where the clasts are limestone and the fracture filling matrix is a calcareous (13 per cent) diatomaceous claystone. Apparently the fractures were open at one stage to allow deposition of fill which may have migrated upward from below with fluids. The carbonate mineral is low magnesian calcite. 


\section{PLATE 1}
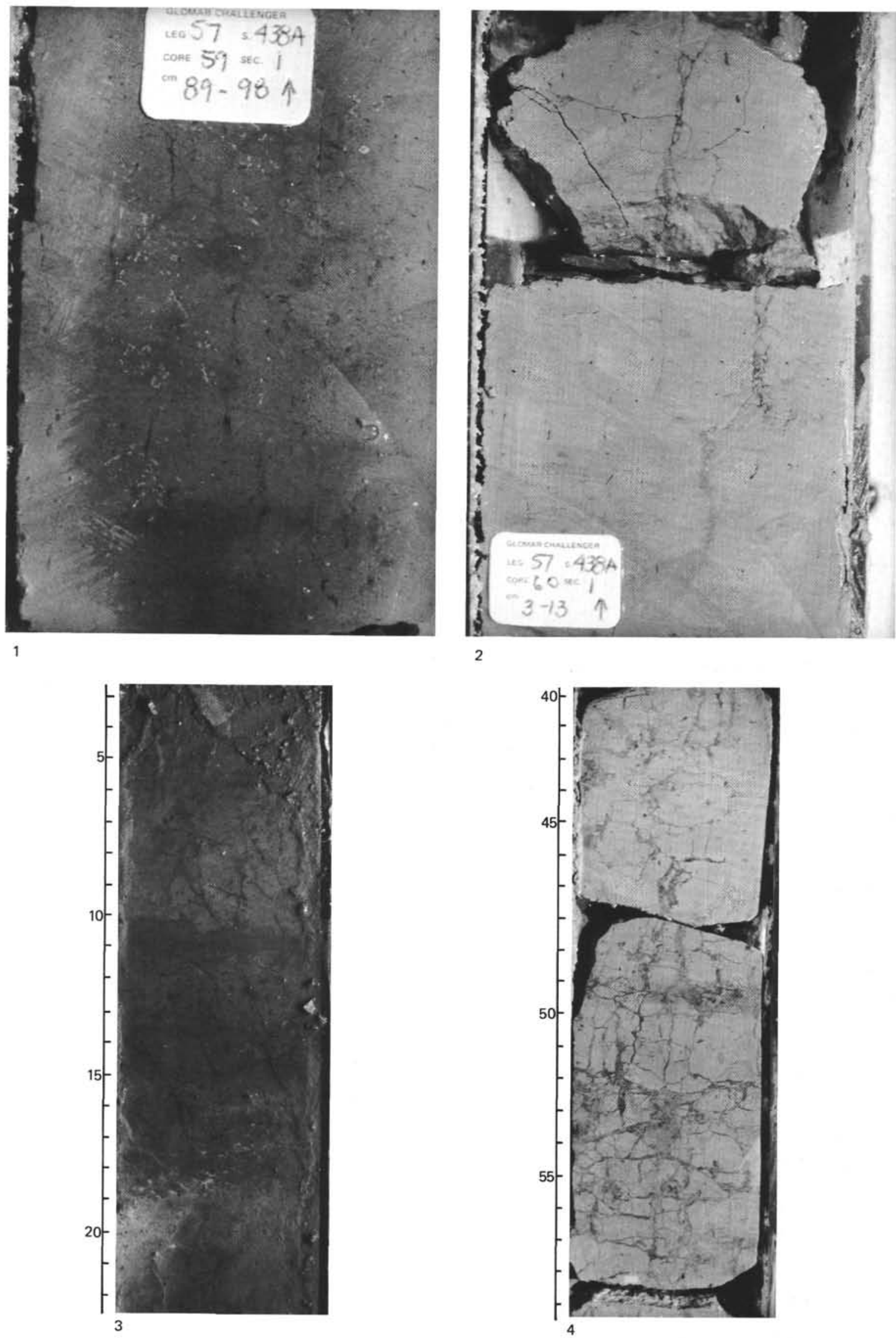


\section{PLATE 2}

Veins and Microfaults on the Deep Sea Terrace

Figure 1 Sample 438A-71-1, 8-17 cm (727 m sub-bottom): Dewatering veins above and below calcareous mudstone associated with the intersection of two fractures (broad horizontal bands). Fractures are near vertical, but core face intersected them at an oblique angle.

Figure 2

Sample 438A-72-1, 124-133 cm (737 m sub-bottom): An intersection of two microfaults where the vertical fracture is cut perpendicular to the plane of fracture and the subhorizontal fracture plane is nearly parallel to the plane of the cut. Note that the rock is generally not fractured except in association with the microfault intersection. This contrasts with intensely fractured sediment in the trench inner slope sites.

Figure 3 Sample 438A-72-1, 47-56 cm (737 m sub-bottom): Anastomosing veins and fractures. Veins are associated with one fracture. Broad dark horizontal trends are actually near-vertical fractures intersected at an oblique angle.

Figure 4 Sample 438B-4-1, 49-57 cm (354 m sub-bottom): A single vertical healed fracture. The fractures from Site 438 are commonly singular, whereas those from sites near the trench are more closely spaced and numerous. Note also that there are few open fractures in contrast to those in cores from the other sites. 
PLATE 2
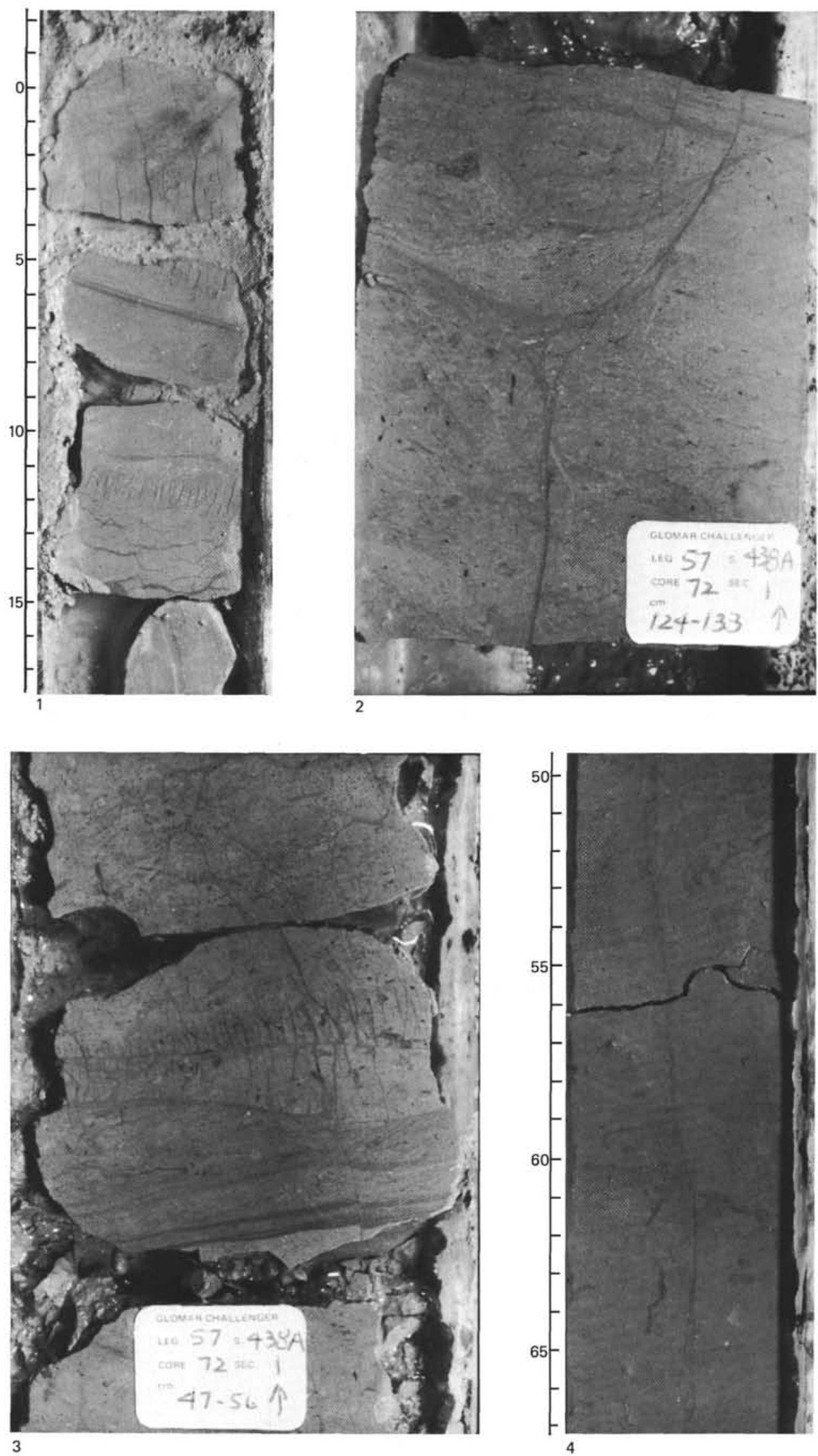
PLATE 3

Microfaults and Veins Associated with Large-Scale Faulting on the Deep Sea Terrace

Figure 1 Sample 438B-7-2, 33-40 (883 m sub-bottom): A zone of isolated microfaults coincident with some small faults seen in seismic records. Interval above and below is unfaulted. Note sharp fault planes.

Figure 2 Sample 439-8-2, 98-117 cm (881 m sub-bottom): Fractures and veins characteristic of deep faulted areas at the landward reference sites (438 and 439). Anastomosing sigmoidal veins form in association with the faults. Offset along this fault is about $12 \mathrm{~cm}$. Note that open fractures do not occur in association with these faults.

Figure 3 Sample 439-8-2, 51-60 (880 m sub-bottom): Detail of veins at an intersection between two major fractures. The subhorizontal wide dark band is a fracture oriented near vertical but intersected by the cut core face at an oblique angle.

Figure 4 Sample 439-11-3, 72-93 cm (910 m sub-bottom): Fault zone containing calcareous concretions. Light-colored bed at 72 to $73 \mathrm{~cm}$ is volcanic ash. Note that the concretions appear to have been rolled while forming in the fault zone. The concretionary growth is good evidence for fluid migration along faults. 
PLATE 3
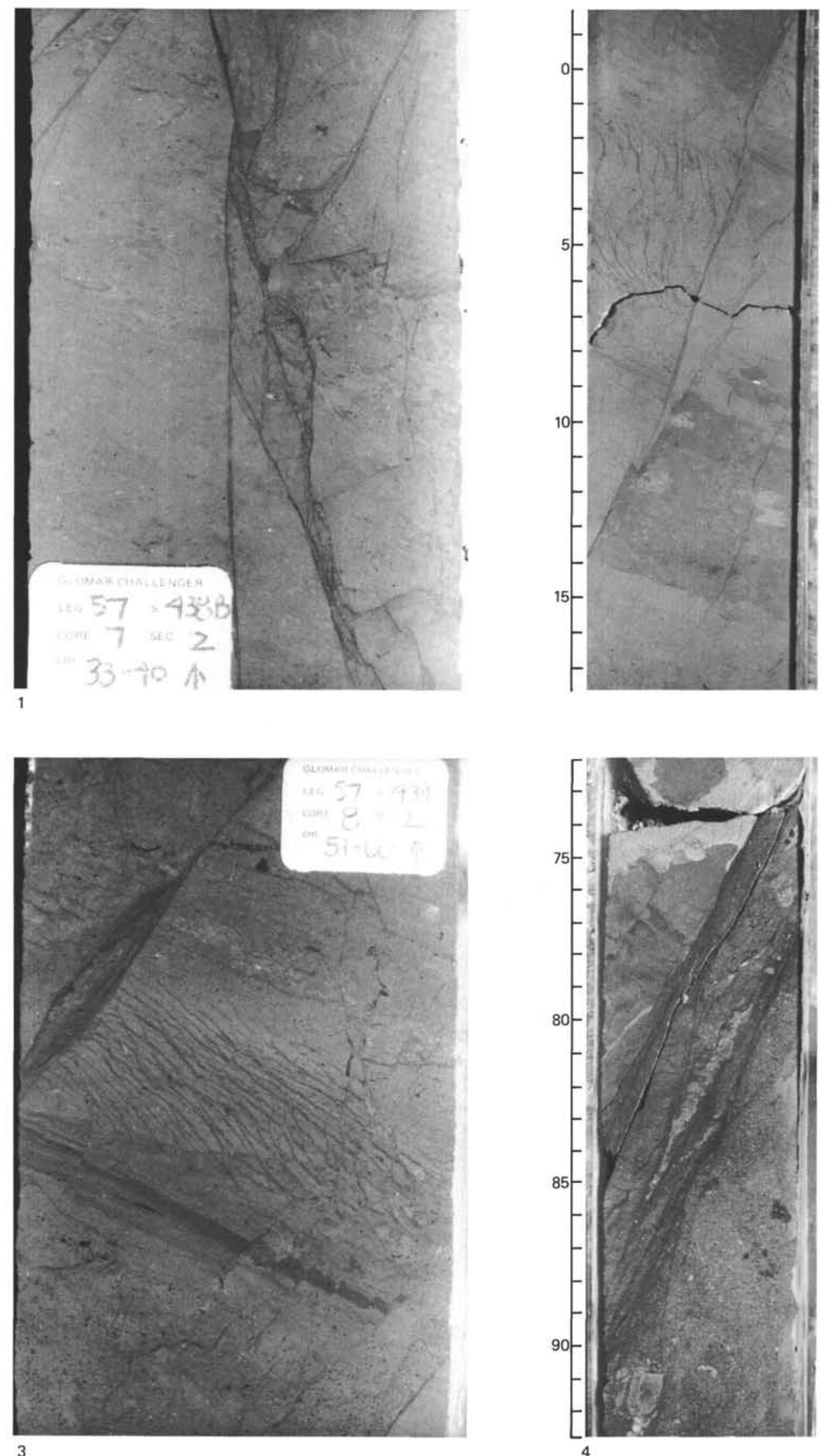


\section{PLATE 4}

Core Disturbance and Fracturing at Midslope Terrace Site

Figure 1 Sample 440B-20-6, 83-104 cm (329 m sub-bottom): "Biscuiting" along horizontal disk fractures similar to that occurring here continues to about $370 \mathrm{~m}$ depth. Most open fractures are induced by drilling; dark traces of incipient veins and some healed microfractures occur (e.g., $87-89 \mathrm{~cm})$.

Figure 2 Sample 440B-24-6, 48-69 cm (367 m sub-bottom): Drill-induced fracturing of core showing the initial stage of breakup leading to the commonly recovered "drill hash" of small lithic fragments. Healed fractures or veins are visible from 60 to $68 \mathrm{~cm}$. Parallelism of drill-induced fracturing and faintly visible healed fractures or veins suggest postrecovery core deformation along existing planes of weakness.

Figure 3 Sample 440B-27-1, 77-86 cm (387 m sub-bottom): Well-developed microfracture fabric shown by offset light-colored laminae. These discontinuous laminae appear to be burrow-fillings of volcanic ash stretched during downslope movement. Bedding dips at about $20^{\circ}$.

Figure 4 Sample 440B-30-1, 26-36 cm (415 m sub-bottom): Diagonal fractures consisting of a dominant set cutting a subordinate set. The texture is nearly that of a tectonic microbreccia. 
PLATE 4
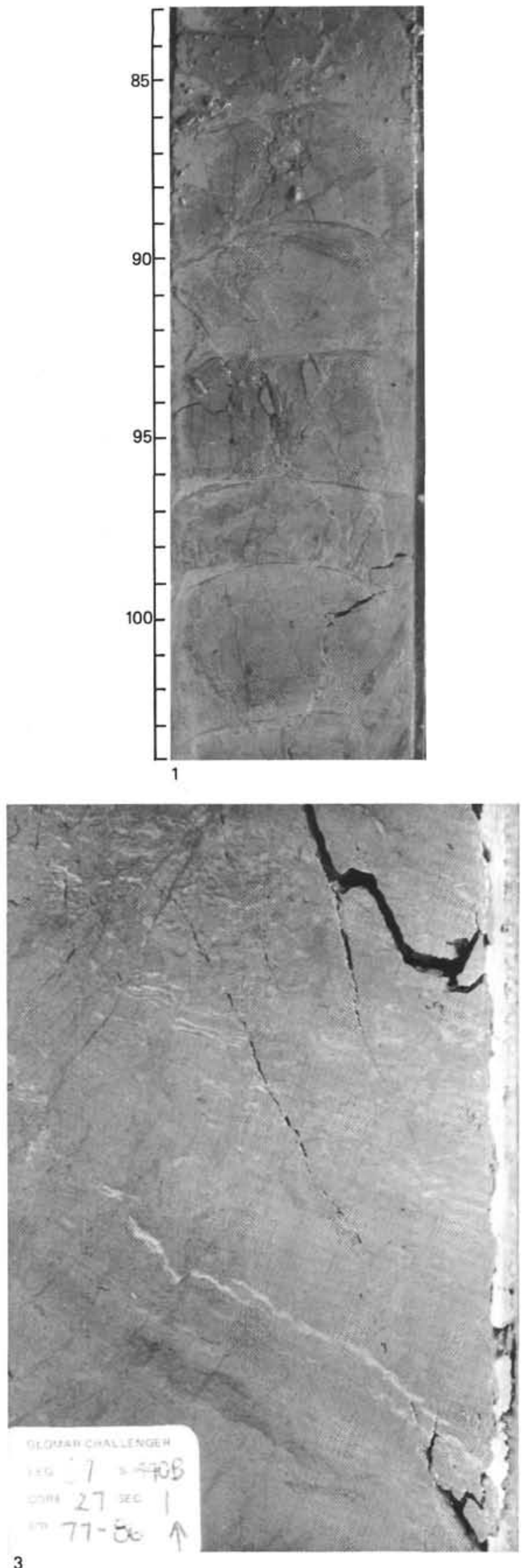
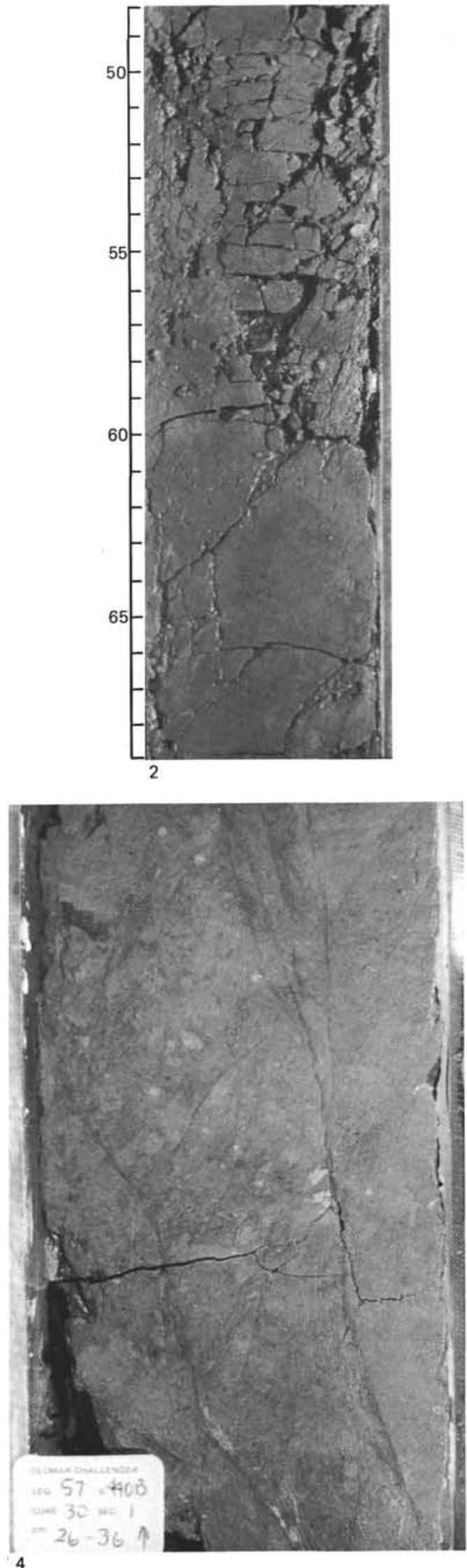
PLATE 5

Fractures and Microfaulting on the Midslope Terrace

Figure 1 Sample 440B-34-1, 54-74 cm (454 m sub-bottom): Drill induced open fracturing paralleling healed fractures and veins. Some healed fractures develop into open fractures.

Figure 2 Sample 440B, 48-4, 84-95 cm (591 m sub-bottom): Highly microfractured core with concentration of dark-colored fill in some fractures. This suggests stages of in situ open fracturing. Note intensity and anastomising nature of microfracturing.

Figure 3 Sample 440B-57-1, 50-58 cm (672 m sub-bottom): Detail of microfaulting; note millimeter offsets, in this case with a reverse sense.

Figure 4 Sample 440B-53-3, 52-72 cm (638 m sub-bottom): A microfaulted resedimented conglomerate. Large open fractures are probably drill-induced. Lithic clasts are best seen in larger pieces of core at top and bottom of photograph. Healed microfractures generally follow clast boundaries and less frequently cut across clasts (e.g., 61-64 cm). 
Plate 5
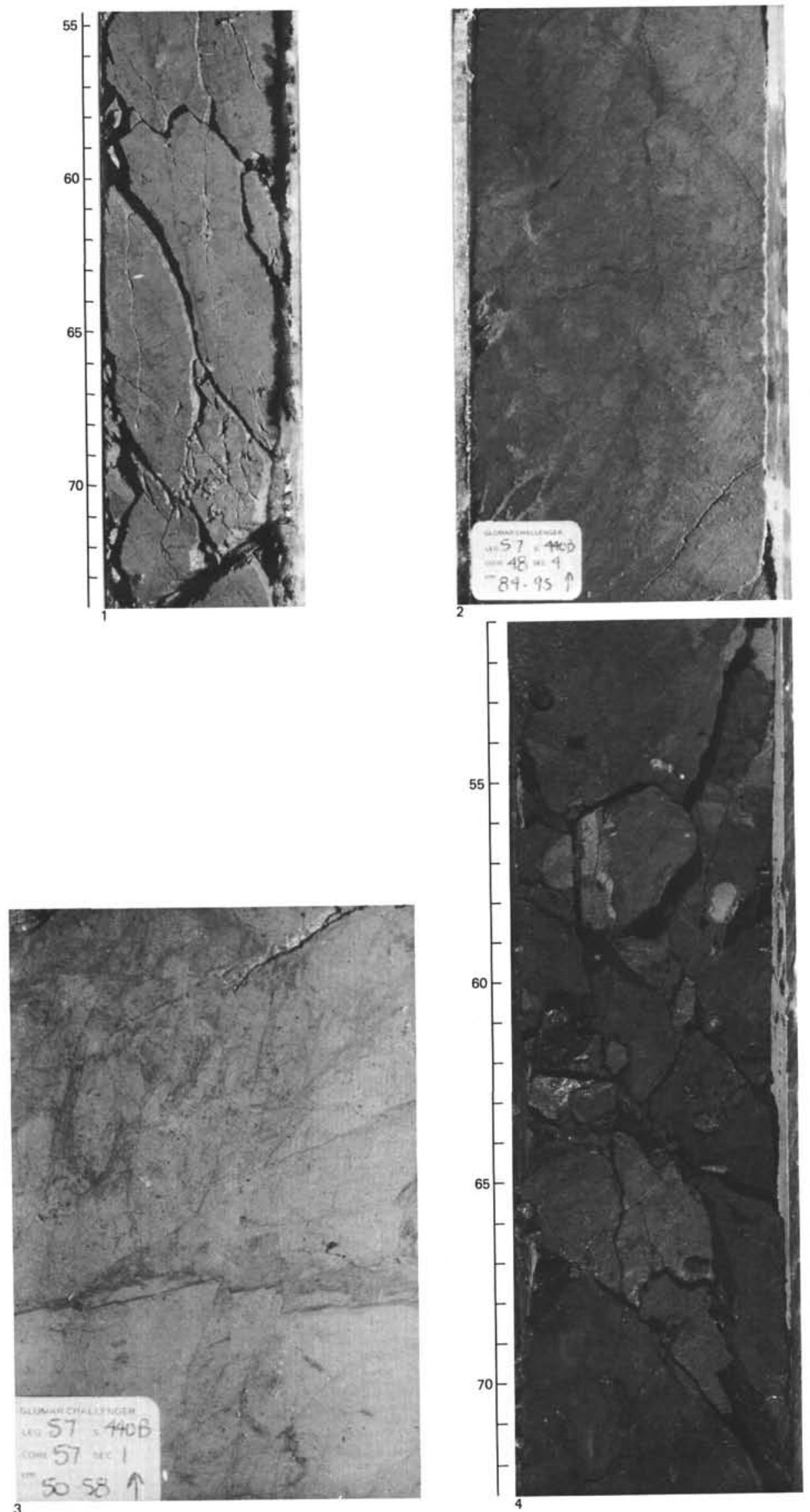
PLATE 6

Fracture Patterns in the Trench Inner Slope

Figure 1 Sample 441A-H1-3, 9-34 cm (approx. $300 \mathrm{~m}$ subbottom): Angular chips of olive green gray mudstone typical of recovery at sites on trench inner slope. The chips, as in this example, often fit together, as though a more coherent core piece had broken along numerous fine, intersecting fractures upon unloading of pressure after the core was raised to the surface.

Figure 2 Sample 441A-H2-1, 139-146 (approx. $350 \mathrm{~m}$ subbottom): Network of closely spaced fractures in highly mottled calcareous mudstone. Fractures here are nearly vertical with a low-angle crosscutting set. Offset along these fractures varies from 0 to $5 \mathrm{~mm}$. Many of the fractures appear to be normal faults. This type of fracture pattern may result in the broken core in Figure 1.

Figure 3 Sample 441A-H1-3, 98-112 cm (approx. $300 \mathrm{~m}$ sub-bottom): More coherent core pieces showing systematic open fractures which usually, but not always, follow the direction of pre-existing, healed fractures. The network of open fractures probably resulted from handling of the core. White-colored zone at about $100 \mathrm{~cm}$ in core is a burrow-mottled volcanic ash layer. A dense network of faint dark fractures can be seen in the middle to upper part of the photo.

Figure $4 \quad$ Sample 434B-4-2, 27-35 cm (316 m sub-bottom): Burrowed vitric, calcareous mudstone with faint, discontinuous black veins and fractures. Certain cored intervals appear to have been less intensely fractured than those shown in Figure 2. 
PLATE 6
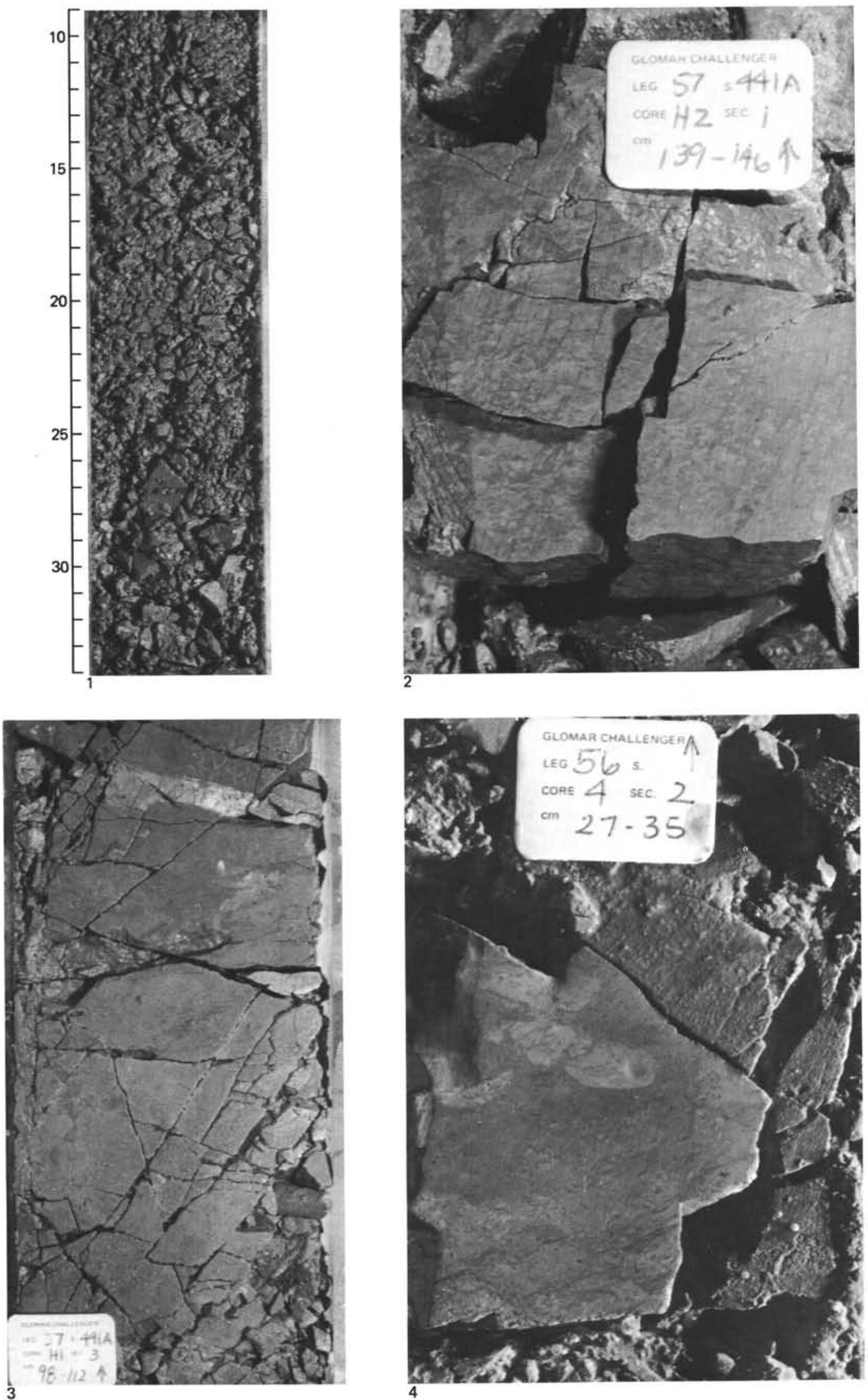


\section{PLATE 7}

Fracture Patterns on the Trench Inner Slope

Figure 1 Sample 434B-15-2, 107-119 (420 m sub-bottom): Several systems of crosscutting microfaults and major offset along an earlier system. Dark vitric mudstone to left is juxtaposed against highly bioturbated calcareous mudstone; this implies offset along near-vertical fault of at least $15 \mathrm{~cm}$. Bedding is near horizontal. The major fault apparently offset faults of an earlier trend which moved slightly subsequently, giving an irregular serration to the fault plane (A).

Figure 2 Sample 434B-15-3, 94-106 (422 m sub-bottom): Clasts of light gray green mudstone $(<5-\mathrm{mm}$ diameter) in matrix of dark olive green mudstone. Bedding dips about $40^{\circ}$. This unit probably represents a fluidized flow containing more indurated angular pieces of mudstone derived from upslope.

Figure 3 Sample 434B-15-3, 115-128 (423 m sub-bottom): Sharp, perpendicular open fracture sets, probably produced during core recovery. These planes appear to follow a pre-existing slight foliation in the mudstone.

Figure 4 Sample 434-28-2,CC (256 m sub-bottom): Brecciated mudstone with some porosity in fractures; most fractures filled with light-colored calcite microspar. Relatively little movement has occurred between pieces of the breccia. 
PLATE 7
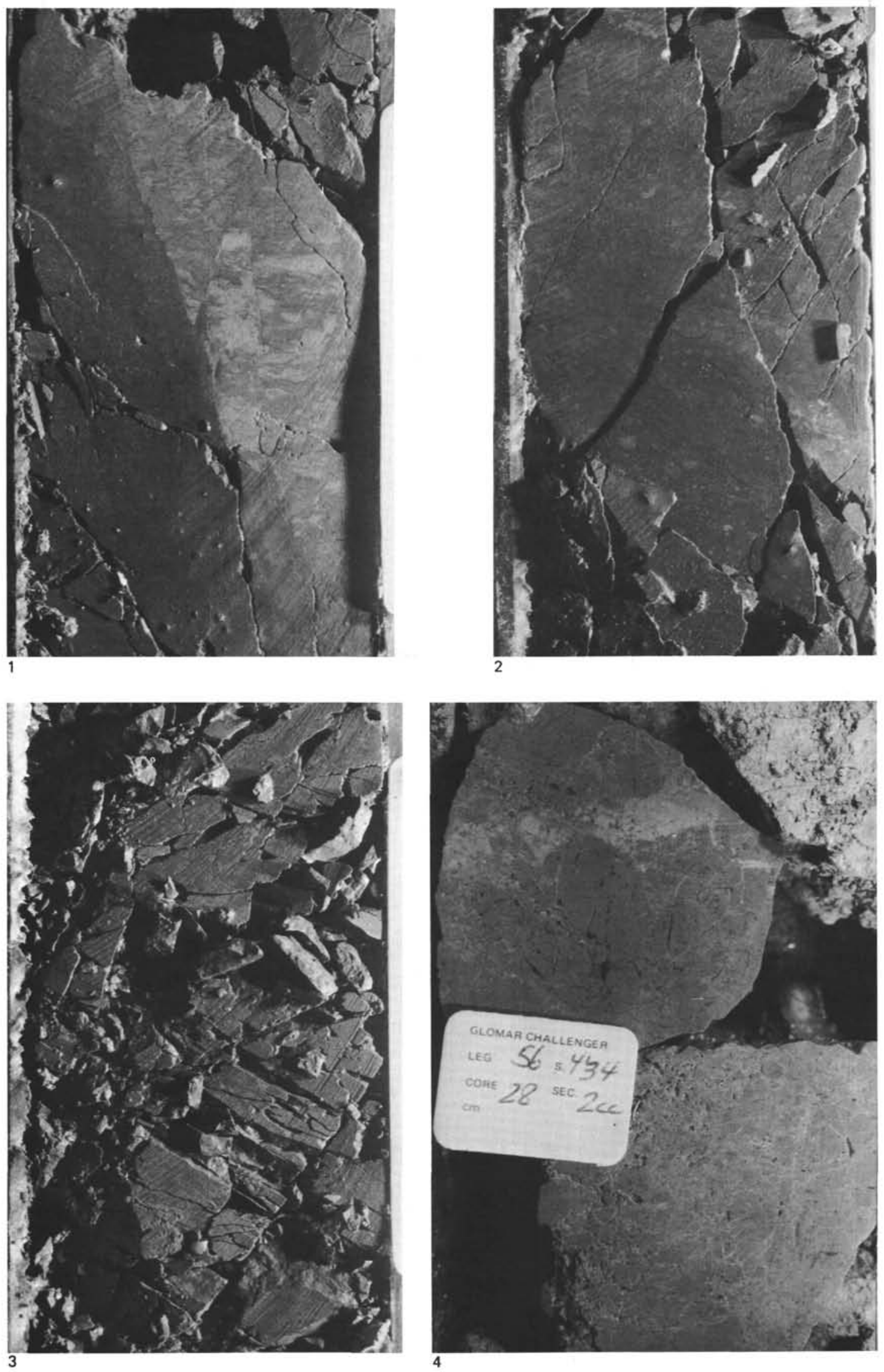


\section{PLATE 8}

Fracture Patterns in the Trench Inner Slope

Figure 1 Sample 434B-10-1, 73-93 cm (372 m sub-bottom): Example of highly fractured vitric diatomaceous mudstone which has disintegrated partially into chips upon recovery (e.g., Plate 6, Figure 1). This is probably the reason why recovery was so poor in the trench inner slope holes.

Figure 2 Sample 434B-10-1, 10-12 cm (372 m sub-bottom): A $1 \mathrm{~cm} \times 2 \mathrm{~cm}$ chip from the same core as Figure 1 . Note grooves and steps on fractured surface. Steps are the result of intersection of fracture planes and face in the direction of movement of the block which moved against the one shown.

Figure 3 Sample 434B-28-1, 54-73 cm (543 m sub-bottom): Core barrel filled with chips of mudstone, again showing some sections of nearly coherent core.

Figure 4 Sample 434B-29,CC (561 m sub-bottom): Monolithologic breccia of dark brown mudstone cemented by white sparry calcite. Many clasts are fractured, and fractures have been filled by calcite. Textures suggest redeposition postbrecciation movement of clasts. 
PLATE 8
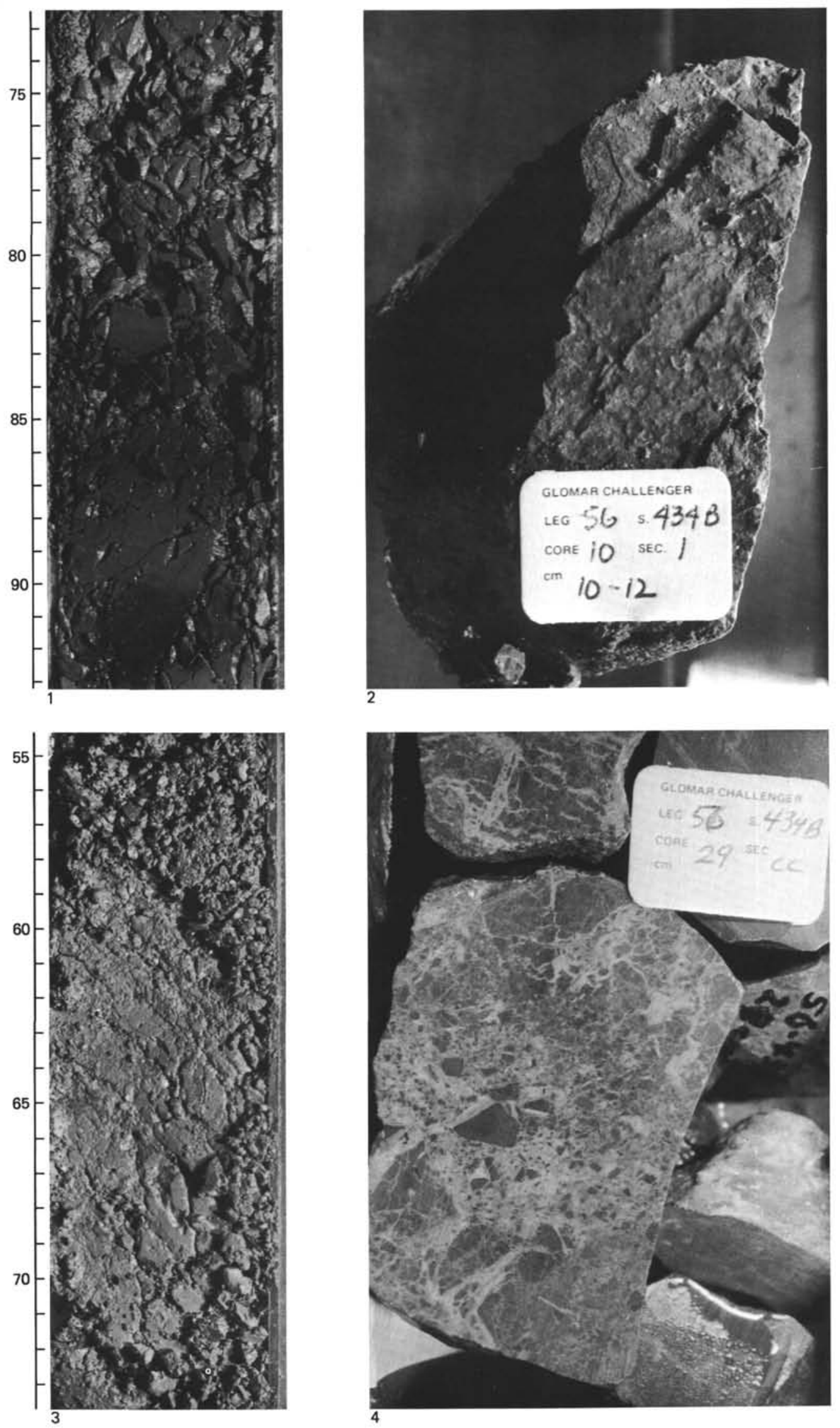
PLATE 9

Fabric of Diatomaceous Mudstone

Figure 1 Sample 440-6-4, 140-142 cm (49 m sub-bottom): Plane light; field width $=1.5 \mathrm{~mm}$. Open framework of randomly oriented diatom fustules, siliceous sponge spicules, volcanic glass, quartz, and feldspar (section normal to bedding).

Figure 2 Sample 438B-4-6, 140-142 cm (862 m sub-bottom): Plane light; field width $=1.5 \mathrm{~mm}$. Compact diatomaceous claystone with silt-sized volcanic glass, quartz, feldspar, and pyrite. Note more preferred orientation of diatoms in plane of bedding, in contrast to Figure 1, and lack of totally flattened fabric. Burrowing tends to disrupt orientation, forming swirls of elongate of platy grains (section normal to bedding).

Figure 3 Sample 441A-H2-1, 90-92 cm (336.5-386 m subbottom): plane light; field width $=1.5 \mathrm{~mm}$. This sample is an indurated diatomaceous mudstone in a highly fractured zone. Again most diatom frustules are flattened in the plane of bedding, but some are oriented out of that plane (section normal to bedding).

Figure $4 \quad$ Sample 434B-10-1, 0-11 cm (371.5 m sub-bottom): Plane light; field width $=1.5 \mathrm{~mm}$. Note swirled texture and varying orientation of diatom frustules in diatomaceous claystone. This sample is from about the same depth as that shown in Figure 3 and is also a highly fractured interval. Very little preferred orientation has been developed (section normal to bedding).

Figure 5 Sample 434B-28-1, 23-26 cm (542.7 m sub-bottom): Plane light; field width $=1.5 \mathrm{~mm}$. Silty vitric claystone with no apparent preferred orientation of elongate grains (section normal to bedding). 
PLATE 9
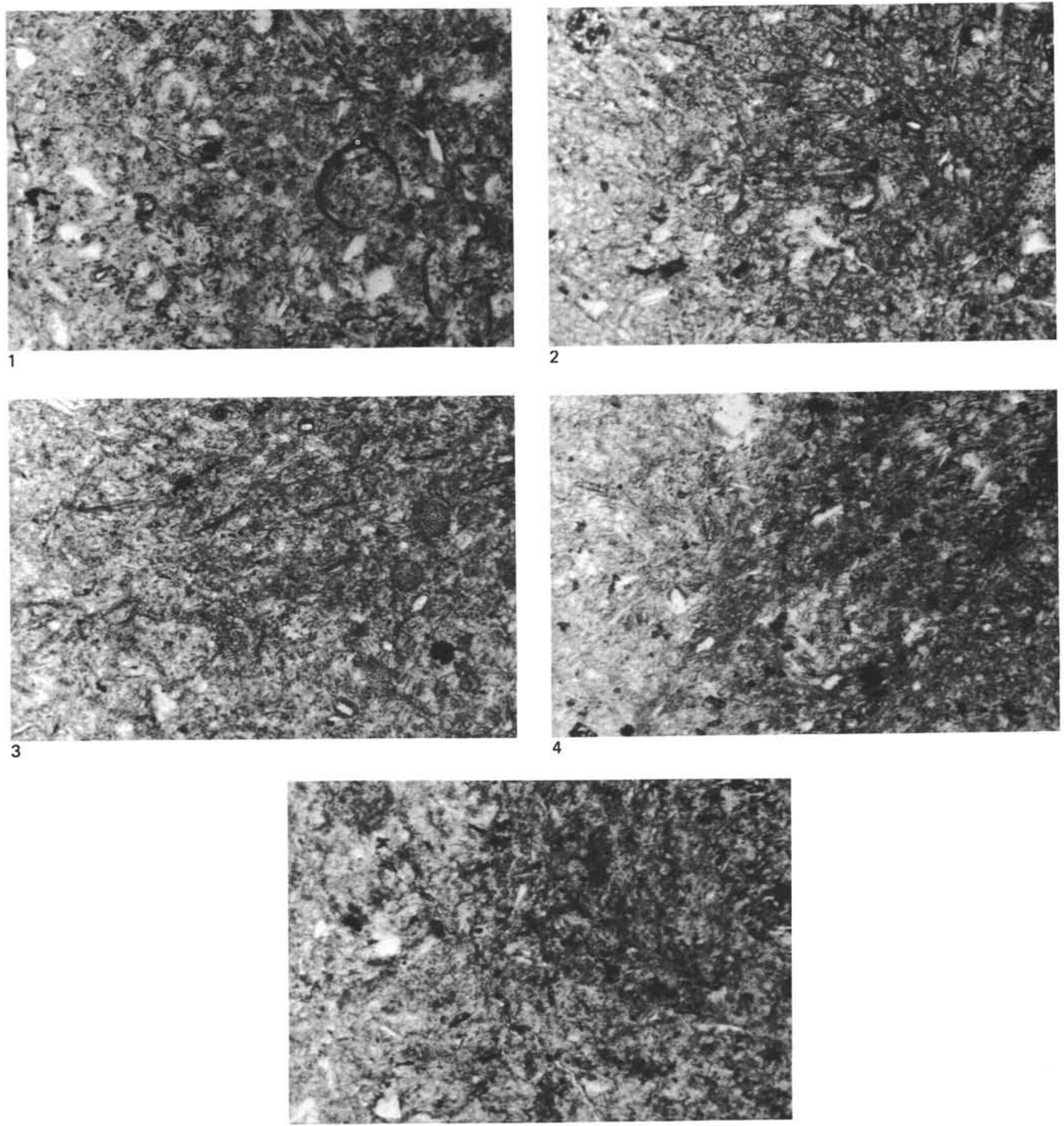

5 
PLATE 10

Photomicrographs of Fractures in Trench Slope Sediments

Figures 1, 2 Sample 441A-10-2, 52-54 cm (578 m sub-bottom). Figure 1: Crossed nicols; field width $=5.7 \mathrm{~mm}$. Redeposited breccia of vitric silty claystone clasts which are angular to subrounded and set in a dark claystone matrix. The unit has been subsequently fractured with little relative movement of clasts; fractures are filled with calcite (section normal to bedding). Figure 2: Crossed nicols; field width $=$ $1.5 \mathrm{~mm}$. Closeup of fracture patterns; clasts as well as matrix are fractured.

Figure 3 Sample 434B-7-1, 35-40 cm (343.3 m sub-bottom): Plane light; field width $=5.7 \mathrm{~mm}$. Mottled calcareous claystone. Note thin, sharp, intersecting fracture planes showing relative offsets. The texture suggests brittle deformation of this indurated calcite-cemented rock (section normal to bedding).

Figure 4 Sample 434B-15-3, 108-115 (422.3 m sub-bottom): Plane light; field width $=1.5 \mathrm{~mm}$. Vitric diatomaceous claystone. Broad fractures (dark intervals) offset one another. Note rotation of diatom frustules into plane of fracture (section normal to bedding). 
PLATE 10
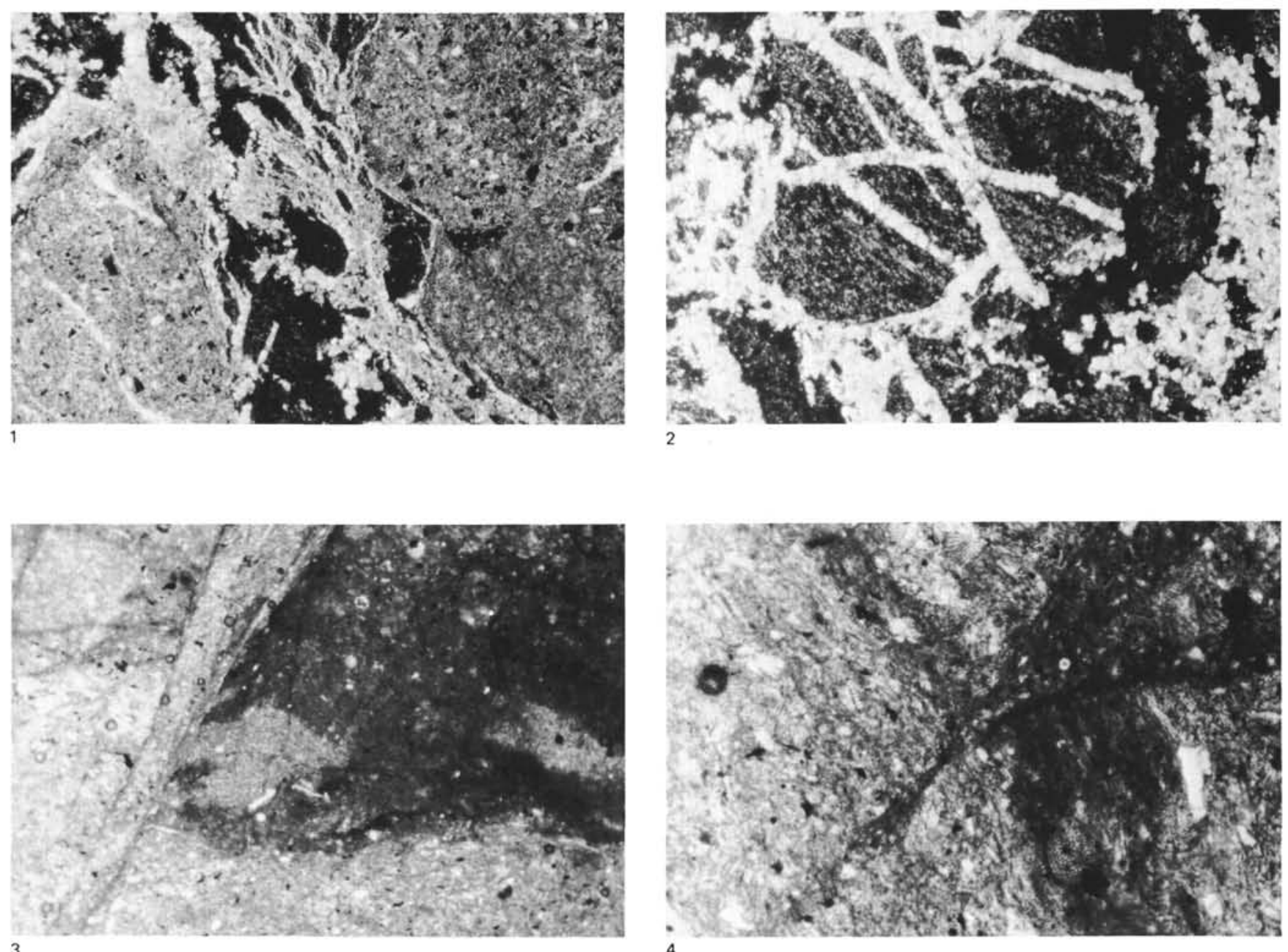


\section{PLATE 11}

Photomicrographs of Fractured Sediments from the

Trench Inner Slope (Sample 434B-8-1, 120-126 cm, $353.7 \mathrm{~m}$ subbottom, all plane light section normal to bedding)

Figure 1

Figure 2

Figure 3

Figure 4

Figure 5
Field width $=5.7 \mathrm{~mm}$. Fracture in vitric diatomaceous claystone (center right-vertical). Diatoms outside of fracture are oriented subparallel to bedding. No diatoms are visible within fracture zone, and grain size generally decreases within the zone from the edges. Elongates quartz grains are aligned parallel to the fracture orientation.

Field width $=1.5 \mathrm{~mm}$. Closeup of right-hand margin of fracture zone. Diatoms are apparently truncated along the fracture. Note that the size of quartz grains is generally smaller within the fracture zone on the left side of the photo.

Field width $=5.7 \mathrm{~mm}$.

Field width $=1.5 \mathrm{~mm}$.

Field width $=5.7 \mathrm{~mm}$. Fracturing apparently causes reorientation of grains both within and on the margin of the fractured zone. Brittle and structurally weak grains such as diatom frustules are easily comminuted; quartz grains are less so. 
PLATE 11
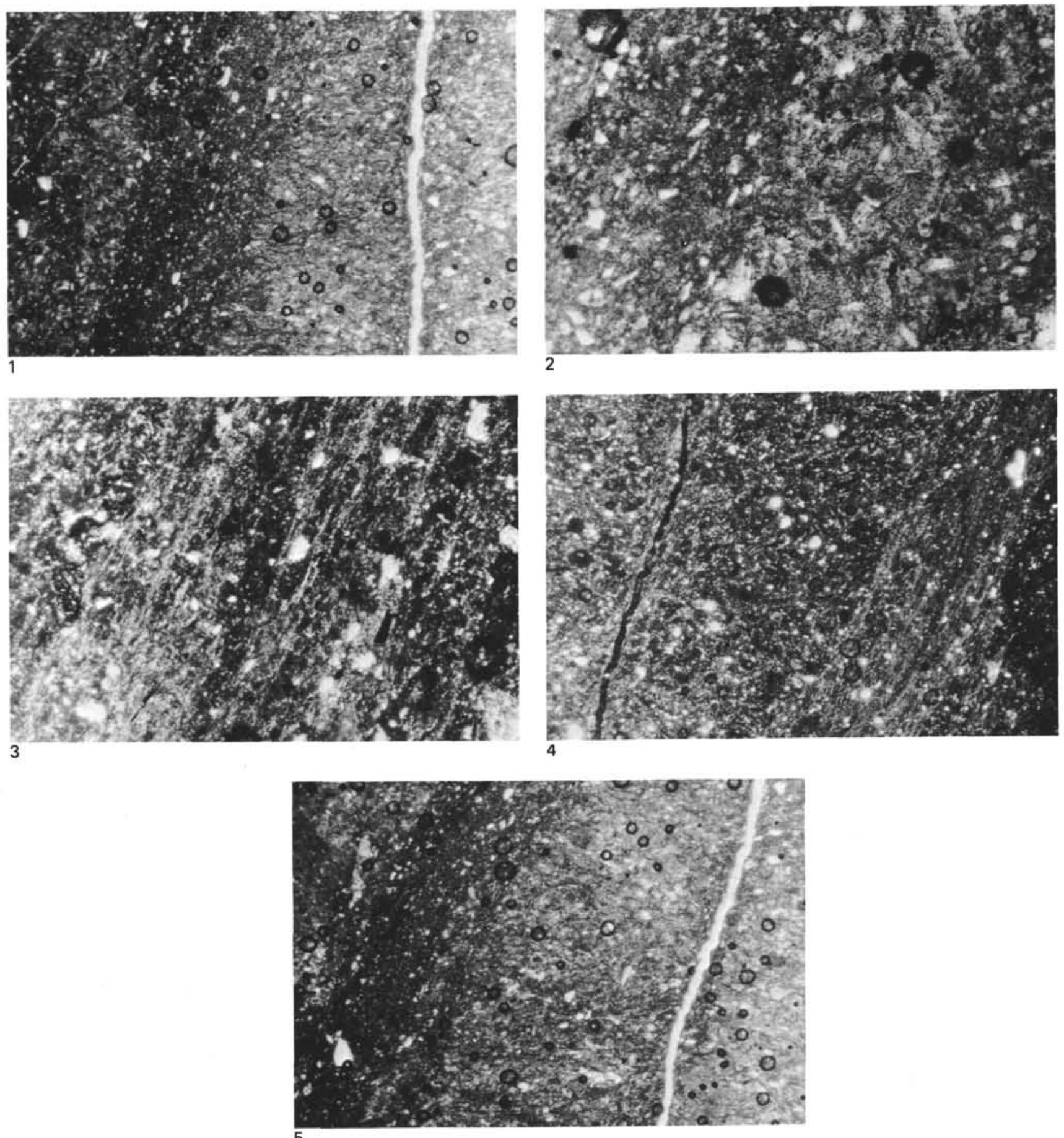
PLATE 12

Surface Texture of Fracture Planes

(Sample 434B-9-1, 112-115 cm, $363 \mathrm{~m}$ sub-bottom).

Figure 1 Low magnification photomicrograph (looking down in bedding surface) of intersecting fracture system; note steps formed at intersection. Fracture surface texture is smoother than freshly fractured rock surface.

Figure 2 Magnification view of fracture surface showing grooves and steps along surface of movement (movement of opposite block was toward the lower left corner of the photograph).

Figure 3 Surface of fracture showing grain-size diminution within fracture, probably due to breakage of grains during movement along fracture or to finergrained material migrating into and along fractures with fluids. Note absence of diatom fragments. Material consists mainly of densely packed, fine-grained quartz and clay minerals. The chemistry of this material (Figure 5) is roughly similar to that of the bulk rock (Figure 6) as determined by semiquantitative analysis by KEVEX fluorescence unit.

Figure 4 Typical matrix of diatomaceous mudstone at same scale as that of fractured material in Figure 3. Note more open pore framework and abundance of diatom remains in contrast to that shown in Figure 3.

Figure 5 KEVEX pattern of chemistry of fracture material shown in Figure 3 sample rich in $\mathrm{Si}, \mathrm{Al}, \mathrm{Fe}$, and $\mathrm{K}$.

Figure 6 KEVEX pattern of chemistry of bulk rock shown in Figure 4; composition similar to that in Figure 5. 
PLATE 12
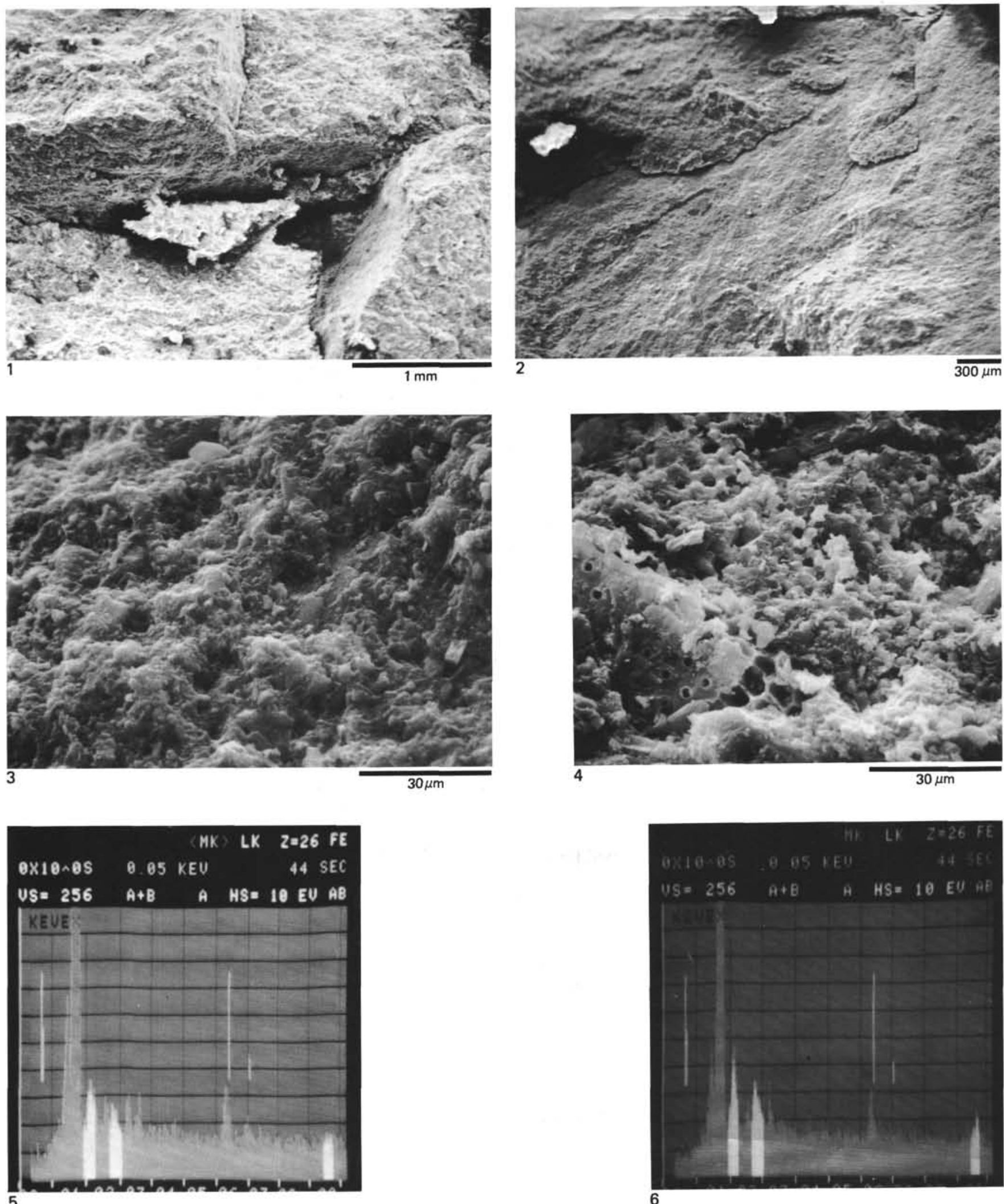
PLATE 13

SEM Comparison of Fracture or Vein Surfaces with Freshly Fractured Surfaces

Figure 1 Hole 438A wash core (from $750 \mathrm{~m}$ sub-bottom): Smooth texture on dark vein surface. Vein orientation in core was nearly vertical (perpendicular to bedding). Note general lack of systematically oriented steps or grooves along vein surface. There was no evidence of movement along this vein in core. However, note the preferred orientation of diatom frustules parallel to vein surface; orientation of diatom frustules in unveined or unfractured part of rock is more random and subparallel to bedding. This implies rotation of diatoms into the plane of the vein due either to slight movement along vein or to the pressure of fluids migrating upward along the vein.

Figure 2 Sample 439-7-3 (872 m sub-bottom): Surface of dark vein. Note preferred orientation of clay flakes (probably mica-illite) parallel to vein surface. There was no evidence in core for offset along this set of veins.

Figure 3 Sample 439-7-3 (872 m sub-bottom): Freshly fractured surface approximately parallel to bedding of same sample as shown in Figure 2 and at same scale. Note irregular surface break, orientation of larger clay mineral flakes subparallel to bedding, and random orientation of diatom frustules. 
PLATE 13
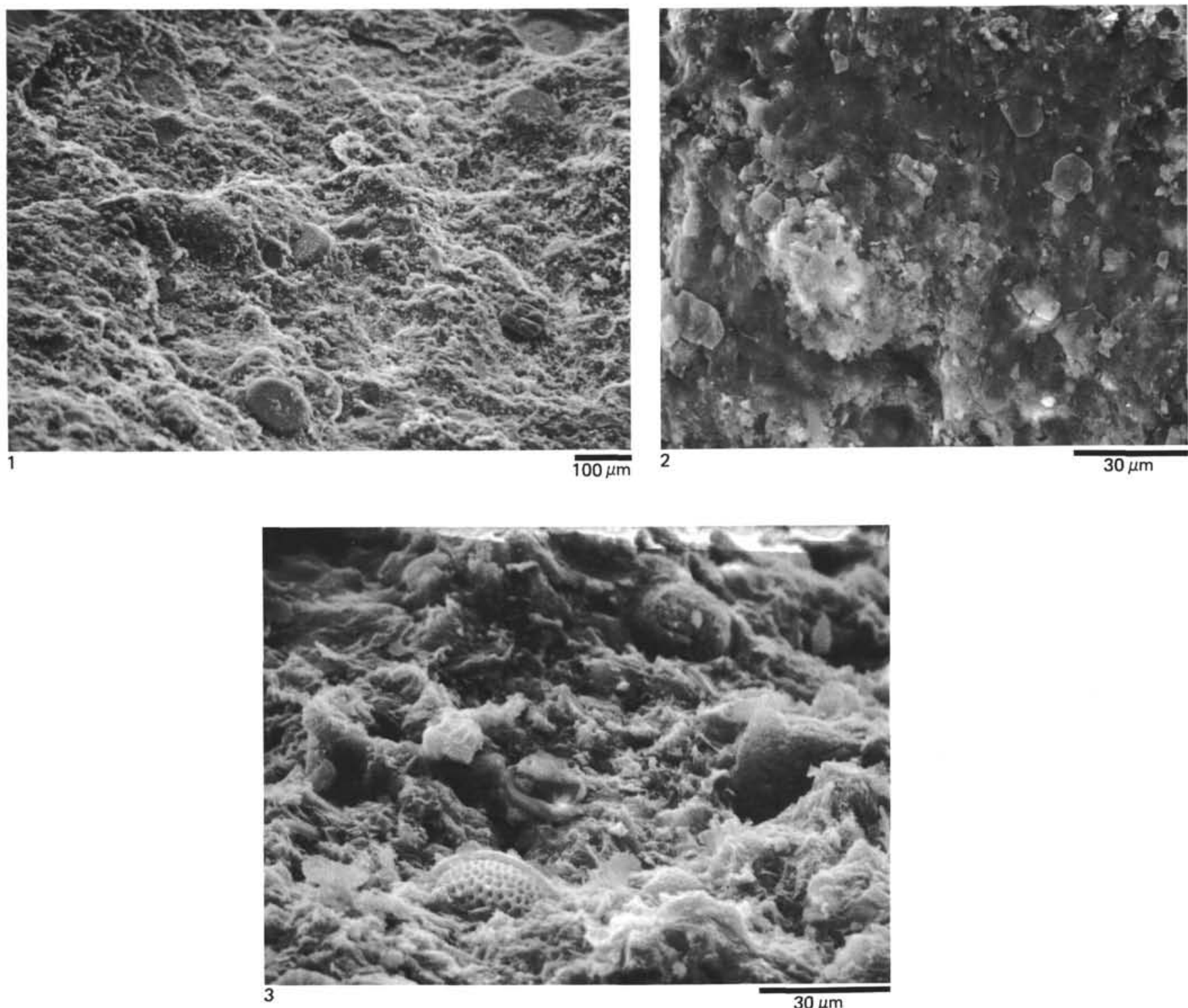